\title{
LA CONDENA DE LE SILLON, UN EPISODIO DE LA CRISIS MODERNISTA, 25 AGOSTO 1910
}

\author{
POR \\ CRISTÓBAL ROBLES MUÑOZ \\ Instituto de Historia, CSIC, Madrid
}

\begin{abstract}
RESUMEN: La crisis modernista puede estudiarse desde los mismos modernistas y desde su posición frente a los que los combatieron acusándolos de conspirar contra el catolicismo. Pueden estudiarse la oposición contra ese plan y la estrategia de sus adversarios. Este trabajo la estudia. Analiza las presiones llevaron a la condena de Le Sillon el 25 de agosto de 1910 Se utiliza la documentación existente en el Archivo Secreto Vaticano. Aporta los información que recoge y acepta la encíclica del Papa Pío X. La Santa Sede se desligó de un movimiento que seguía la opción de León XIII aceptando abiertamente la República y la democracia.
\end{abstract}

PALABRAS CLAVES: Le Sillon, Marc Sangnier, Pío X, Merry del Val, Umberto Benigni, Emmanuel Barbier, Henri Louis Chapon, Eudoxe-Irenée Mignot, Le Grand Sillon, Louis Billot, Action Action Française, Notre Charge Apostolique

\section{CONDEMNATION OF LE SILLON, AN EPISODE OF THE MODERNIST CRISIS}

(25 August 1910)

ABSTRACT: The modernist crisis can be studied from the same modernist and from the position against those who attacked accusing them of plotting against Catholicism. Can be analyzed the opposition against this plan and strategy of their opponents. This paper studies it. Analyzes pressures led to the conviction of Le Sillon the August 25, 1910, with existing documentation in the Vatican Secret Archives. It provides the information collects and accepts by the encyclical of Pope Pius $X$. The Holy See dissociated himself from a movement that was the option to accept openly the Republic and democracy in France.

KEY WORDS: Le Sillon, Marc Sangnier, Pío X, Merry del Val, Umberto Benigni, Emmanuel Barbier, Henri Louis Chapon, Eudoxe-Irenée Mignot, Le Grand Sillon, Louis Billot, Action Française, Notre Charge Apostolique

$\begin{array}{ll}\text { Recibido/Received } & 20-09-2012 \\ \text { Aceptado/Accepted } & 25-03-2013\end{array}$

El ascenso de Le Sillon fue una pesadilla para los anti-modernistas. Lo examinaron con atención y lo denunciaron como una desviación de la ortodoxia y 
una estrategia para dividir a los católicos en Francia, ${ }^{1}$ en un momento difícil para la Santa Sede en sus relaciones con la República Francesa. ${ }^{2}$ Este trabajo se sitúa en el marco de un estudio sobre el modernismo. ${ }^{3}$ Analiza la condena de Le Sillon en 1910, atendiendo, sobre todo, a la oposición del grupo de la Correspondence de Rome y de Umberto Benigni y de sus socios. Fue un episodio de aquella crisis. Su contexto es la crisis del movimiento católico en Italia, con la aparición de la Lega Democratica Nazionale. El conflicto entre los católicos alemanes, a cuenta de la desclericalización, que afectó a las relaciones entre las dos corrientes sindicales y abrió el debate sobre la fidelidad del Zentrum católico a sus orígenes y a la Santa Sede. $^{4}$ En Francia se evaluaba los resultados del "ralliement" y se sacaban consecuencias que apuntaban en direcciones contrapuestas. ${ }^{5}$

Le Sillon ha sido estudiado antes en algunos de los aspectos que aparecen aquí: su afinidad con los democratacristianos, ${ }^{6}$ con el movimiento social católico, ${ }^{7}$ con la figura carismática de Marc Sangnier. ${ }^{8}$

1 Basta citar algunos escritos del director de La Critique du Libéralisme. Barbier, Emmanuel. 1905. Les idées du Silllon. Étude critique: Poitiers: Imprimerie Blais \& Roy / Paris: Librairie P. Lethielleux; Le Sillon, qu'a-til répondu à la brochure "Les idées du Sillon", Paris ; 1906. Les idées du Sillon. 1906, Étude critique, Poitiers: Imprimerie Blais \& Roy / Paris: Librairie P. Lethielleux; 1906. Les erreurs du Sillon, Erreurs de doctrine, Erreurs sociales, Erreurs de polémique et de conduite. Poitiers: Imprimerie Blais \& Roy / Paris: Librairie P. Lethielleux, sans date ( 1906); 1907. La décadence du "Sillon". Histoire documentaire Paris; 1907. Le progrès du libéralisme en France. Sous le pape Léon XIII, 2 vol. Paris 1907.1906. Rome et l'Action Libérale Populaire. Histoire et documents. Poitiers: Imprimerie Blais \& Roy. París: Librairie J. Victorion. 1906. Cas de conscience. Les catholique français et la République (4), Paris : Letheillieux; 1908. Les démocrates chrétiens et le modernisme. Histoire documentaire. Poitiers: Imprimerie Blais \& Roy / Paris: Librairie P. Lethielleux; 1910. Le devoir politique des catholiques. Articles extraits de la Critique du Libéralisme,

Paris: Jeuve et cie 1910. Una colección de La Critique du Lbéralisme, en Bibliothèque Saint Libère http://www.liberius.net/livre.php?id livre=435. Brillaud Maurice, et Chiron. Yves 2005.L'abbé Emmanuel Barbier (1851 - 1925). Paris : Lapidaire Clovis. Barbier, recordaba B. Joassart, al concluir su reseña sobre este libro: « «ll y a de tout, en effet, dans ses procédés: de la puérilité, de la méchanceté, du mensonge aussi et souvent, hélas! de la calomnie». Es una cita de La Semiane Religieuse de Toulouse, aparecida en 1912. La reseña de Bernard Joassart, en 2008. Nouvelle Revue Théologique, 130/2 : 297. Desgranges, Jean. 1905? Les vraies idées du Sillon, , Paris : Cic \& Amat Libraires-Editeurs; 1909. Réponse à la Revue Le Sillon, Limoges: Imprimerie Ouvrière., janvier 1909,

${ }_{2}^{2}$ La situación de Marc Sagnier la definió Charles Maurras como un dilema. 1908. Le dilemme de Marc Sangnier. Essai sur la démocratie religieuse. Paris: Nouvelle Librairie Nationale. Hay una reedición en 1921.

3 Robles Muñoz, C. 2006. "Vísperas de la Pascendi: II Santo de Antonio Fogazzaro y el encuentro de Molveno", Hispania Sacra 118: 683-753. 2007. "Alfred Loisy, más allá del ruido y del humo", Hispania Sacra 118: 633-706; 2003 (edit. 2011)“La Pascendi Dominici Gregis (1907) vista desde los modernistas", Anthologica Annua 50: 11-166. 2012 . "¿Qué modernismo hubo en España?", en La "primera" modernidad. Modernismo religioso y literario en España e Hispanoamerica, (eds) Luis de Llera y Cristina Asssumma. Bogotá: Editorial Planeta Colombiana: 111-151.

4 Robles Muñoz, Confesionales versus interconfesionales. La Santa Sede y los católicos alemanes (1907-1922), trabajo en prensa en Anthologica Annua, 210 páginas

5 Sobre Piou, Flornoy Eugène. 1907. La lutte par l'association : l'action libérale populaire. Paris: Librairie Lecoffre. Gabalda \& $C^{\text {ie }}$; Denais, Joseph. 1959. Jacques Piou, un apôtre de la liberté. Paris: La Neuf de Paris Editions. Vendroux, Evelyne Janet. 2012. Jacques Piou et l'Action Libérale Populaire (1901-1914), cuyo origen es una tesis bajo la dirección de Gilles Le Béguec, Université de Paris, Pantheon-Sorbonne, defendida el 29 de junio de. 2012. Algunas obras de Piou en

http://www.amazon.fr/s/ref=ntt_athr_dp_sr_1/276-4030330-8672457?_encoding=UTF8\&fieldauthor=Jacques\%20Piou\&search-alias=books-fr\&sort=relevancerank

6 Caron, Jeanne. 1967, Le Sillon et la Démocratie Chrétienne. Paris: Plon. 
La Santa Sede tenía un informe detallado de la implantación de Le Sillon. Estando su diario prohibido por Roma, tenía el apoyo del clero. No era necesario, pues, asistir a las reuniones de los círculos de estudios y a las asambleas "sillonnistes" para estar en comunicación con Le Sillon todos los días. Los católicos se fiaban de ese periódico, porque Marc Sangnier se declaraba hijo fiel de la Iglesia. Por eso no percibían que su doctrina era heterodoxa. No era condenable su opción republicana. Sí, su actitud y sus ideas. Marc Sangnier era una persona orgullosa, con una formidable tenacidad. ${ }^{9}$ Sustituía a la Iglesia en la interpretación del Evangelio. Sus principios sociales eran subversivos. Iban contra la familia y la desigualdad, que existirá siempre. Ni ricos ni pobres, ni señores ni siervos, ni gente que mande ni otros que obedezcan, ni patronos ni obreros. Todos cooperadores. Era una utopía que empujaba a perseguir un ideal imposible.

Era acertada su crítica de un catolicismo formalista, ajeno a la vida, mero ritual de determinados momentos de la existencia. Pero Marc Sangnier no acusaba a quienes hacían esa separación entre fe y moral, sino a la Iglesia, pues no había sabido predicar el Evangelio. Pretendían mostrar a todos el núcleo del mensaje de Jesús, pues la Iglesia no supo hacerlo.

Le Sillon era un modernismo social, como había dicho el P. Fontaine. No era Marc Sangnier un verdadero hijo de la Iglesia. Tenía prohibido hablar en todas las diócesis, salvo en París. Y del otro lado, estaba Paul Sabatier, para quien Marc Sangnier era el católico que más cercano al ideal protestante. ${ }^{10} \mathrm{El}$ movimiento estaba bajo vigilancia en 1910. Examinaremos los antecedentes anteriores a Pío X.

Loisy en noviembre de 1893 que León XIII no tenía más objetivo que la dominación política de la sociedad. No podía soportar que hubiera recomendado el estudio de la Biblia estrangulando la exégesis. Estaba en contra de la revolución, pero animaba a los cristianos demócratas.

Todos los sacerdotes que conocía deseaban una apertura doctrinal, pero la juzgaban irrealizable. No compartía Loisy esa conclusión, porque creía que, en el orden moral, la voluntad puede mucho. Sólo son ineficaces la indecisión, la inercia

${ }^{7}$ Fabrègues, Jean de. 1964: Le Sillon de Marc Sangnier. Un tournant majeur du mouvement social catholique. Paris; Perrin.

${ }^{8}$ Barthélemy-Madaule, Madeleine. 1973. Marc Sangnier: 1873-1950. Paris: Seuil. Mayeur, Jean-Marie (sous la direction de) 2006. Le sillon de Marc Sangnier et la démocratie sociale : actes du colloque des 18 et 19 mars 2004, Besançon: Annales littéraires de l'Université de Franche-Comté 807. Série historiques: Presses universitaires de Franche-Comté. Greteau, Jacques. 2009. Marc Sangnier, le semeur d'espérances. Paris: L'Harmattan. Poulat Emile. 2002. Marc Sangnier en 1910. La Lettre "Notre charge apostolique » et ses suites. Paris: Institut M. Sangnier.

L'Institut Marc Sangnier, fondé en 1990 par son fils Jean (1912-2011), conserve les archives et les documents permettant de mieux le connaître ainsi que les souvenirs. L'Institut possède des fonds d'origine privée constitués principalement par ceux de Marc Sangnier, Francisque Gay, René Lemaire, Henri Colas, Charles Lachaud (avocat et grand-père de Marc Sangnier).

${ }^{9}$ En una polémica entre François Laurentie, dos años después de separarse de Le Sillon, sostuvo una polémica con sus antiguos camaradas sobre la participación de los "sillonistes" en la elaboración de las ideas del movimiento. Conclía que el movimiento era Marc Sangnier "puis qu'il ne peut pas, lui, ne pas en être... nulle idée et nul individu ne peuvent en être que par lui...Une idée de Marc Sangnier, prouvée ou non, est sillonniste de ce fait seul qu'elle sienne". Barbier, Emmanuel.1907. La décadence du "Sillon". Histoire documentaire(2); 206-242. Paris

${ }_{10}$ Cuadernilllo sin firma ni fecha, autógrafo, ASV Segr.Stato 12 (1910) 17 312-340. Hay una lista detallada de sacerdotes por diócesis con la aportación que hacen para diario de los "sillonnistes". En total entregaban unos 30000 francos. "Paul Sabatier... semble s'être donné ou avoir reçu cette mission spéciale: protestantiser l'esprit des catholiques...", Barbier, Emmanuel. 1907: 149. 
y la renuncia a actuar. Entre sus amigos laicos, la mayoría estaba en la democracia cristiana. Le Sillon nació en este tiempo. Antes de instalarse en Neuilly, conoció a Marc Sangnier, aún alumno del Saint Stanislas, el colegio de los marianistas, en París.

"Si la réforme catholique était une folie, disons qu'un vent de folie tournait alors les meilleures têtes dans le catholicisme français: la mienne doit être excusable de s'y être laissée emporter. Excusable ou non, j'ai poussé jusqu'au bout mon expérience". ${ }^{11}$

El 23 de enero de 1927, Henri Bremond comentaba la actitud de Pío X con Le Sillon y con la Action Française. La rectificación, hecha por parte de la Santa Sede ¿implicaba endosar a Pío X la responsabilidad del "la terreur anti-moderniste"? El Papa fue duro con los sillonnistes, cuya única culpa fue "avoir cru à l'Évangile". ${ }^{12}$

El contexto en que el que surge Le Sillon y las influencias recibidas son imprescindibles para entender un movimiento cuyas ideas son "si fugaces dans ses expressions". Entre ellas, los demócratas cristianos, los modernistas, las relaciones entre ambos grupos y su influjo en el movimiento social cristiano.

En cuanto a los cristianos demócratas hay que remontarse a su origen y a sus antecedentes: los "católicos sociales" y los círculos de obreros católicos.

Los primeros, nacidos tras la crisis de 1870, trataron de crear una solidaridad entre las diferentes clases de la sociedad. Sus fundadores, a la vista de las condiciones de vida de los trabajadores, estudiaron los problemas económicos y se pusieron como objetivo la puesta en pie de un orden social católico. Fue el marqués de la Tour du Pin un personaje clave. Los círculos fueron católicos y legitimistas. Su fracaso coincidió con el de la ley de asociación sindical de 1884, tan restringida, que sólo permitió a los sindicatos funcionar como una asociación de descontentos. Fueron meras plataformas para la propaganda revolucionaria.

En 1890 aparece una nueva generación de católicos. Fueron los años del boulangisme. ${ }^{13}$ Cansado de ver cómo los católicos de la generación anterior fueron rechazados por la República, tomaron de ellos la intransigencia. En aquellos momentos los católicos eran respetados en Estados Unidos. Habían triunfado sobre el Kulturkampf en Alemania. En Bélgica habían llegado al poder. Quisieron los sillonnistes adaptar el catolicismo a las exigencias de la sociedad moderna para poder actuar estar eficazmente en la vida pública. Había que rehabilitar al creyente ante las masas, dominadas por la increencia.

Para conseguirlo habría que suprimir del catolicismo todo lo que no era esencial, que, como lastre del pasado, impedía avanzar más rápido. Gentes de acción, no dudaron en hacer concesiones, pues estaban seguros de triunfar. Fue la generación de la Rerum Novarum. Con esa aportación el movimiento se amplía y se desborda.

${ }^{11}$ Loisy, Alfred. 1930. Mémoires pour servir à l'histoire religieuse de notre temps, tome premier 1857-1900: 365. Paris, Émile Nourry Éditeur.

12 Poulat, Émile. 1972. dossier historique previo a, Une oeuvre clandestine d'Henry Bremond. Sylvain Lebrand, Un Clerc qui n'a pas trahi. Alfred Loisy d'après ses mémoires. 1931 : 44. Roma: Edizioni di Storia e Letteratura.

13 Levillain, Philippe. 1983. Boulanger, fossoyeur de la monarchie. Paris: Flammarion. Garriges, Jean 1991. Le général Boulanger. Paris: Olivier Orban; 1992. Le Boulangisme. Paris: PUF, coll. « Que-sais-je ? », 2698. 
Surge entonces el católico que teme no ser suficientemente moderno. Cuando, dentro de este movimiento, apareció una corriente democrática se separó del movimiento social católico. Surgió entonces, aunque modificado, el catolicismo liberal: hay que reconciliar a la Iglesia con el mundo moderno bajo el signo de la libertad y de la supresión de todas las barreras sociales. ${ }^{14}$ La democracia será la conjunción de la libertad y de la igualdad y no podría sostenerse si no era cristiana. Servirla era la mejor manera de servir la causa de Dios y la causa del hombre. ${ }^{15} \mathrm{La}$ Iglesia tenía que aliarse con los pueblos, no con los poderes.

En el terreno político hubo otro cambio profundo. Los católicos comenzaron a buscar un encuentro con sus conciudadanos. León XIII les pidió que no se empeñaran tercamente en una oposición política ineficaz. Muchos, animados por ese consejo de León XIII y cansados de luchar, se hicieron "constitucionales", es decir, aceptaron la República. Fueron los "ralliés". Había "un esprit nouveau", que trastocaba ideas recibidas y principios tradicionales. ${ }^{16}$

Al hacer balance, el resultado no fue alentador. La Iglesia había cedido en beneficio exclusivo de los otros. ${ }^{17}$ Había que reflexionar. No podría continuar la imitación, sin más, del catolicismo norteamericano, marcado por su espíritu democrático e individualista. Tras celebrarse durante la Exposición Universal de Chicago (1893), un Congreso Mundial de las Religiones, Victor Charbonnel presentó un proyecto de "union morale des religions", para preparar un nuevo Congreso con motivo de la Exposición Universal de 1900. La base era un pacto de silencio sobre las diferencias dogmáticas, el abandono de los viejos fanatismo y la acción común en todo lo que une a las gentes y las perfecciona.

Estaba esa propuesta en la honda de la "Union pour l'Action Morale", que agrupaba a librepensadores, neo-cristianos y algunos democratacristianos. Toda esa corriente conocida luego como americanismo, tuvo expresión en la traducción de la Vie du P. Hecker, aparecida en 1897 con una carta del cardenal James Gibbons, arzobispo de Baltimore, y una introducción de Jonh Ireland, arzobispo de Saint Paul, Minnesota. El 22 de enero de 1899, León XIII en su Testem benevolentiae condenó el movimiento. ${ }^{18}$

Las ideas democráticas siguieron su curso. El americanismo abogó por el "sentimiento democrático". Los modernismos trataron de introducir la democracia

${ }^{14}$ Los discursos de John Ireland fueron traducidos al francés con el título, 1894. L'Église et le siècle (Felix Klein, éd.) Paris: V. Lecoffre...

${ }^{15}$ Los católicos intransigentes hablaron del partido de Dios como su lugar de enganche y de lucha frente a una sociedad que deseaba echarlo fuera. Unir a Dios y al hombre será el rasgo más saliente y a la vez, la raíz de las confusiones que crearon y de las que fueron acusados los católicos demócratas.

${ }_{16}$ Sobre el ambiente de estos añios, Robles Muñoz, Cristóbal. 1992. "En el corazón de la democracia. León XIII y Francia", Anthologica Annua 39: 168-321. "Léon XIII, presentant les temps nouveaux, avait volulu placer I'Eglise au coeur de la démocratie par ses actes, dont la portée depasse notre pays et notre siècle, quoiqu'isl en béneficient tous d'abord". Charles MoureyRampolla, 8 julio 1892, ASV Sgr.Stato 248 (1900) VI 67-68

${ }^{17}$ Uno de los detalles que destacará Ariès será el valor que los demócratas cristianos daban a la aprobación de os masones. "L'alliance de fait en politique, des déomcrates chrétiens avec les partis les plus avancés, manifestemen inféodés aux loges, est avoué partout". Ariès, N. 1910. Le Sillon et le mouvement démocratique: 72-73. Paris: Nouvelle Librairie Nationale. Esta obra se presenta vinculada a la de Emmanuel Barbier y Mgr. Henri Delassus, el director de la Semaine Religieuse de Cambrai, Ibídem: X.

${ }^{18}$ Carta dirigida al cardenal James Gibbons, Leonis XIII Pontificis Maximi Acta, v. XIX, Roma $1900,5-20$. 
en la Iglesia. Uno y otra venían exigidos por esa táctica de concesiones que hizo que Paul Desjardins definiera esa situación como "conversion de l'Église".

Vinieron luego los Congresos Eclesiásticos de Reims (1899) y de Bourges (1900). ${ }^{19}$ Iban en esa misma dirección: asimilar a Iglesia con las instituciones civiles. A partir de esto, fueron apareciendo las diferentes facetas del modernismo, recogidas en la Pascendi Dominici Gregis el 8 de septiembre de 1907.

\section{LOS DEMÓCRATAS NO SON MODERNISTAS}

Estos antecedentes permiten comprender Le Sillon, pero no identificarlo con el modernismo, aunque lo hayan hecho sus adversarios y los modernistas a quienes ha interesado presentar como tal a Marc Sangnier y a sus seguidores. ${ }^{20}$

Los demócratas no son modernistas. Sus excesos y equivocaciones no deben hacer olvidar sus esfuerzos en favor de las clases humildes, mediante el estudio de las cuestiones sociales y la renovación religiosa. Han sabido reaccionar contra clamorosas injusticias. No habían aceptado una unión ficticia, propiciada por una política electoral sin horizonte y sin ideas. No creían que una sociedad nueva saliera del traspaso del poder desde la izquierda a los conservadores.

"Les conceptions étroites et superficielles au nom desquelles on les a souvent cambattus sont pour eux une excuse. S'i ils ont manqué de bon sens et de mesure, ils n'ont pas manqué de générosité et de bon zèle"

En Le Sillon habían hallado buena tierra todas las semillas democráticas. Habían crecido "avec la plus surprenante fertilité". ${ }^{21}$

Así lo veían sus enemigos. Frente a quienes creyeron que el problema de $L e$ Sillon radicaba en Marc Sangnier y su personalidad fascinante para sus seguidores, ${ }^{22}$ hay que señalar que la situación es más compleja y tiene un alcance mayor. Muchos habían criticado a Sangnier y se habían apartado de él. Si se le condenara, otros recogerían su herencia. Bastaba mencionar las "Semaines Sociales" de Francia, creadas por Henri Lorin y bajo su dirección.

"Il faut s'empresser du "port d'attache" où toutes ces corsaires du modernisme pratique ont leurs approvisionnements et leurs arsenaux. Ce "port d'attache", c'est l'utopie du "démocratisme".

El sentido mesiánico de la democracia procede de la influencia judía, presente en Le Sillon y en otros grupos parecidos. Según la confesión de los masones judíos, el Mesías es la revolución. ${ }^{23}$

19 Remond, René. 1964. Les deux Congrès ecclésiastiques de Reims et de Bourges (18961900.) Paris : Sirey, Coll Histoire et Sociologie de Eglise 4.

${ }^{20}$ Condenado por la Pascedi Dominici, el modernismo perdió influjo en los institutos católicos debido a las medidas contra sus seguidores. Sólo en París conservaban su posición. "'C'est tout profit pour le Sillon, car si sillonisme n'implique pas modernisme, inversement on ne voit guère de modernisme qui, s'étant prononcé sur des questions politiques et sociales, n'ait pas manifesté ses sympathies et offert son concours au Sillon", Le Sillon et le mouvement démocratique... 267.

${ }^{21}$ Ariès, N. 1910: XII-XXXV.

22 "Le Sillon et Marc Sangnier. Notes Confidentielles", sin fecha, pero antes de 1910, ASV Fondo Benigni 8 1084a 420-421.

23 "Remarques au sujet des "Notes Confidentielles su le Sillon et sur Marc Sangnier", sin fecha, pero antes de 1910, Ibídem: 423. 
En sus inicios Marc Sangnier fundó grupos confesionales, según sus palabras. Le Sillon era un movimiento católico. Pronunció sermones, habló de Cristo, llevó a sus amigos en peregrinación a Roma, acumuló bendiciones episcopales. Buscó que en sus Congresos estuvieran presentes obispos y cardenales. Presidió vigilias nocturnas ante el Sacramento. Dirigió palabras "místicas" a seminaristas y religiosas. Su revista tenía como divisa: Revue d'Action Sociale Catholique.

Los "sillonnistes" llevaban una vida religiosa especial, que será su mayor originalidad. Era un organización mixta, cuya dirección era compartida por sus jefes laicos y por la autoridad eclesiástica "dans une affectuese entente".

Cuando F.-V. Dubillard, obispo de Quimper, prohibió el 1 de agosto de 1906 su Congreso, Marc Sangnier apeló a su condición de movimiento laico y político para reivindicar su autonomía y librarse de se modo de la prohibición. Este comportamiento, plenamente legítimo, marcaba la ambigüedad y este alejamiento de los obispos se produjo cuando la Iglesia sufría en Francia cerco y persecución. Fue además un error de funestas consecuencias. Cerró los ambientes católicos a la propaganda demócrata y, desencadenó un conflicto con los obispos, dando un argumento más a quienes acusaban al catolicismo de ser incompatible con la democracia. ${ }^{24}$

Marc Sangnier se equivocaba creyendo que en la Iglesia todos eran iguales. Ese error fue denunciado por el ex obispo de Le Mans, Abel Gibert. A diferencia de lo que sucede en el protestantismo, los seglares católicos sólo pueden hablar de dogma y moral si están en íntima unión con el episcopado y con el Papa. ¿Estaba eso en tela de juicio?

Una vez decidida esta orientación, a partir de 1906, quedaba en juego si habría que subordinar la vida religiosa de los "sillonnistes" a una dirección laica. Era justamente lo contrario a lo que sostenía Marc Sangnier, partidario de que la acción económica y política de Le Sillon no dependiera de los obispos. Este era el punto central del desacuerdo del grupo de Limoges con Marc Sangnier. ${ }^{25}$

La marcha hacia lo que se llamó esos años "Le Grand Sillon" era una opción por la acción política. Fuera un avance o un retroceso, ¿suponía una contradicción con sus objetivos? Para educar para la democracia bastaba "Le plus étroit Sillon". Esta tarea podría ser hecha por una minoría, que nada tenía que ver con "la majorité dynamique" de la que se hablaba tras el cambio. Ahora no era "le petit nombre". Esta evolución podría ser la más clara confesión del fracaso del ideal "sillonniste". Era el punto de vista expuesto en una carta dirigida a Demain. ${ }^{26}$

La explicación de toda la evolución del movimiento estaba en la personalidad de Marc Sangnier, presuntuoso, sin preparación, dispuesto siempre a lanzarse de cabeza en todas las corrientes de acción y de opinión para apoderarse de ellas, pasar de una a otra, abandonarlas sin dejar más huella que una agitación estéril y

24 Jacques Roedel, secretario de Le Sillon, atribuyó la responsabilidad del conflicto a los obispos, porque dejaban que los capitalistas les impusieran cadenas de oro y, una vez roto el concordato, expresaron sin temor sus sentimientos antirrepubblicanos. Pío X estaba contra Marc Sangnier, porque, a diferencia de León XIII, era un Papa reaccionario hostil a las aspiraciones democráticas. Jean Desgranges, Réponse à la Revue Le Sillon: 65. Limoges, janvier 1909, 65

${ }^{25}$ Ariès, N. 1910: 35-43.

${ }^{26}$ Demain era una revista publicada en Lyon, que dejó de aparecer en 1907, después de que tuviera problemas con la autoridad eclesiástica. Representó y fue portavoz en Francia de "toutes les aspirations de réforme soit sociale soit religieuse", sin confundirlas, pero uniéndolas. Ariès, N. 1910: 39-41. 
destructora, capaz de contradecirse a sí mismo, pero sin reconocer jamás una equivocación. Ese ir y venir fue una de las causas de la separación del grupo de Limoges. Se pedía a todos una incondicional "profession de foi sangnieriste". ${ }^{27}$

Junto a la fidelidad confesante de su fe y su obediencia a la autoridad de la Iglesia, fue la política el otro factor que permitió el crecimiento de Le Sillon. Aunque se declaraba partidario entusiasta de la república y de la democracia y criticaba a quienes no eran de esas mismas ideas, Marc Sangnier negaba siempre que estuviera haciendo política. Era, simplemente, "se placer sur le terrain constitutionnel". En esos momentos había una sensibilidad en el catolicismo francés que hacía ver con horror cualquier gesto de oposición al régimen. Ese fue el camino trazado por el "ralliement".

Marc Sangnier no supo sostener su independencia respecto a los obispos y la permanencia de Le Sillon como una organización no política. Si lo hubiera sido, estaba en su perfecto derecho de pedir libertad de acción. Pues los obispos, en ese terreno, no son "les chefs naturels" de los católicos. Pero, al trabajar Le Sillon en el terreno social y político, donde los aspectos morales son decisivos, no cabía actuar fuera de la obediencia a quienes en la Iglesia tienen la misión de defender la pureza de las costumbres cristianas. Le Sillon se presentó en 1907 como una obra de acción social católica. ${ }^{28}$

En 1899 los demócratas cristianos se definieron como un partido político no confesional. Los "sillonnistes" entraron en la acción social por la puerta de su fe católica. Lentamente se encaminaron a la otra puerta que tenían delante: la política. Era lógica esa evolución. La religión se presentaba como un medio para afianzar la democracia. Ahora habría que esperar a descubrir otros medios más eficaces.

¿Alguna estrategia orientó esa marcha? Los enemigos de Le Sillon estaban convencidos de que existía. Lo sucedido desde que en 1899 Marc Sangnier regresó de Toul, donde estuvo destinado como subteniente de ingenieros, a la vista de la coincidencia con otros compañeros de ideas y de proyecto y de la fuerza con que desplegaron su propaganda en los meses inmediatos, apuntaba a un plan no improvisado, según Ariès. A su favor estuvieron quienes, sin examinar sus ideas, se fijaron sólo en el ardor con que testimoniaban su fe y en la fuerza con la que trabajaban para acercar la Iglesia al pueblo.

Por eso en lugar de suscitar desconfianza, Le Sillon fue bien acogido, creció y alcanzó su mayor esplendor, su cenit, en 1905, justo el año en que su revista pasa a denominarse Revue Catholique d'Action.

En febrero de 1907, en el Congreso de Orleans, anunció Marc Sangnier su intención de crear "Le Grand Sillon" donde pudieran estar protestantes y librepensadores con tal de que fueran demócratas y republicanos. Era ya un grupo de católicos, pero no católico. En esa marcha hacia adelante se produce una situación en la que Le Sillon ya no se apoya en la Iglesia, "mais comme le sentiment religieux reste son principal moteur et qu'il ne se reconnaît pas de maître

27 "Nous avons quitté le Sillon... parce que son organisation intérieure attribue une souveraineté absolue à une personnalité de jour en jour plus inquiétante". Desgranges, Jean. 1909 : 69 y 75.

${ }^{28}$ Había una cierta ironía histórica. Marc Sangnier se opuso a la formación de un partido católico. Ahora no podía afirmar que Le Sillon lo era sin perder el apoyo de los obispos, que no podían contradecir esa orientación del catolicismo francés desde finales de los años ochenta. Barbier, Emmanuel. 1907: 257-269. 
en dehors du Sillon, Le Sillon est devenu une Église lui-même", dicen sus detractores. $^{29}$

El estilo de vida de los "sillonnistes", la experiencia de la fuerza que les otorga su unidad de acción, tan espontánea, que, para sus adeptos, parece surgir casi milagrosamente, refuerza ese sectarismo con rasgos autoritarios. "Ainsi le démocratique Sillon est constitué comme la plus absolue des monarchies".

Marc Sangnier con su rica personalidad, era un jefe nato, que había inspirado, en sus subordinados, una especie de fetichismo hacia su figura. ${ }^{30}$ Lo era todo. $^{31}$

Se acusaba a Le Sillon de dividir en dos campos enfrentados a los católicos franceses cuando más necesaria era la unidad entre ellos. Se oponía decididamente a los verdaderos católicos a quienes atacaba, a través de la difusión de doctrinas malas y de escritos que quitaban lectores a la buena prensa. Tenían por camaradas a los sin patria y a los socialistas revolucionarios, y por enemigos a los conservadores, es decir, a la gente honrada, salvo que fueran republicanos. Establecían un terreno de entendimiento con los más subversivos y eran refractarios a compartir nada con los partidarios del orden.

Siempre tolerantes con el mal, excusaban a quien lo hacía, pero eran severos con los buenos. Eran unos revolucionarios "qui érigent en dogme intangible ce tissu de sophismes et de contre-vérités qu'est la Déclaration des Droits de l'Homme"

En religión casi todos eran modernistas y todos modernizantes. Atacaban la autoridad, debilitaban el principio de propiedad y sentían debilidad por el protestantismo, por ser más democrático. El Papa, aún no es su enemigo, pero es el "italien", un extranjero, un retrógrado. Poco faltaba para que se consideraran los verdaderos católicos. Los demás serán "papistas". Su respeto a los obispos lo demostraban los clérigos asistiendo a los actos "sillonnistes" y apoyando económicamente su prensa. En Le Sillon pueden estar esos sacerdotes y laicos, cismáticos que buscaba Aristide Briand para llevar adelante el diseño de Iglesia, recogido la Ley de Separación de las Iglesias y el Estado. Sembrando la discordia y actuando sin descanso, Le Sillon era un serio peligro para la Iglesia en Francia, en un momento de transición y de crisis. ${ }^{32}$

En el verano de 1909, Albert Monniot, director de La Libre Parole, hizo una encuesta a los obispos de Francia. Uno de los que respondió fue el obispo de Annecy, Lucien Campistron. Luego, en la Revue du Diocèce d'Annecy, el obispo repitió las acusaciones contra Marc Sangnier. Este y sus seguidores actuaban inspirados por el modernismo y el liberalismo, condenados por la Iglesia.

No era cierto. En sus escritos y discursos habían rechazado siempre cualquier herejía y cualquier opinión heterodoxa. $\mathrm{Si}$, pese a esa voluntad expresa, se habían

${ }^{29}$ Un malintencionado dijo "Le catholicisme c'est le Sillon! Et le Sillon, c'est Marc Sangnier!". Gaucherand, Fréderic. 1910. Pour quoi?... Lettre à un Sillonniste: 6. Lyon. Se trata de un folleto escrito por el director del Express de Lyon.

30 Ariès, N. 1910: 132-174, 242-243 y 255. Sobre las relaciones de Le Sillon con las autoridades de la Iglesia, Ibídem: 189-220.

31 "... le Sillon c'est M. Marc Sangnier, son fondateur, son orateur, son leader... Quand on cherche la pensée du Sillon, on cite M.Marc Sagnier; quand on attaque le Sillon c'est M. Marc Sangnier qui riposte. Otez M. Sangnier, plus du Sillon!. Gaucherand, Fréderic. 1910: 6 pags.

32 Al. Chandenier-Merry del Val, Freiburg im Brisgau, 3 de julio de 1909, ASV Segr.Stato 12 (1910) 17 349-350. Chandenier es un sacerdote francés residente en esta ciudad alemana. 
alejado de la autoridad de la Iglesia, lo lamentaban y pedían que se les indicase en qué para poder rectificar. Estaban en causa la verdad y la justicia. ${ }^{33}$

Campistron cerraba la puerta a un hombre, cuya persona estimaba, pero cuyas concepciones religiosas eran "inaceptables para él", pues turbaban la pureza de la fe. Insistió Marc Sangnier el 7 de diciembre de 1909, pidiendo al obispo que señalara en qué puntos sus opiniones estaban contra la ortodoxia para poderlas reprobar públicamente $o$ que le permitiera defenderse de acusaciones injustificadas. Recurría al obispo como a un padre y como a un juez. Y cumpliendo el consejo del evangelio, volvía a llamar a su puerta. Nada consiguió. El obispo no lo recibió. ${ }^{34}$

Lo más llamativo de Le Sillon y de quienes se identifican con él es la ausencia de espíritu católico. Leen sólo la Biblia, Pascal, Lacordaire, Gratry... Nunca hablan de la Virgen. "Son mysticisme envisage "le Christ" comme un protestant dévot et modéré pourrait le faire". Su devoción a la eucaristía tiene mucho de individual e iluminista. Hay que encontrarse personalmente con el Cristo-Hostia que les permite una posición privilegiada respecto a los demás.

Todos estos rasgos recuerdan a II Santo, las "catacumbas" y los "Caballeros del Espíritu Santo". Podría decirse que los "sillonnistes" consideran la Iglesia como los primeros cristianos, la Sinagoga. Estos iban a rezar al Templo y participaban en el culto de la Sinagoga, pero el cenáculo (el cenáculo de Marc Sangnier) es el lugar donde brota la piedad y brilla la gracia de los tiempos nuevos. A él volverá a descender el Espíritu y de él saldrán otra vez los apóstoles a conquistar el mundo. Marc Sangnier se cree y es aceptado por sus seguidores como un Mesías. ${ }^{35}$

Se acusó a Le Sillon de estar asociado con el judaísmo y la masonería. En 1887, en una convención celebrada en Pittsburg (USA), se formuló el programa de los judíos modernistas, que tuvo una gran influencia en el mundo cristiano. El rabino Felix Adler, uno de los participantes, fundó la "Asociación de Educación Moral", en Nueva York. Su padre. Samuel Adler, fue rabino jefe de la Sinagoga Emanu-El, de esta ciudad. Con enormes recursos, uno de sus objetivos era la fusión de todas las religiones, mediante el rechazo de los dogmas y el estudio racional de todos sus artículos de fe. Adler acababa de abrir en Berlín y Londres dos sedes. Doce años antes se abrió la de París, que tenía como órgano de expresión Les Libres Entretiens.

Esta última contaba con pocos judíos -entre ellos el periodista y escritor francés Joseph Reinach- pero sí con muchos protestantes y masones, algunos de los llamados "abbés démocratiques" y seglares católicos demócratas. Entre ellos, Charbonnel, Dabry, Klein, Naudet...

Se presentó en sociedad organizando el Congreso de las Religiones. Y preparó luego la Ley de Separación. Su papel fue decisivo en el desarrollo de Le Sillon, denunciaban sus adversarios.

33 Pedía Sangnier poder acudir a Annecy para quedar limpios de esas imputaciones, que pesaban sobre su conciencia y su honor de católico. "Votre Grandeur comprendra l'impériux devoir au quel nous obeissons en lui demandant la justice et elle voudra bien agréer l'assurance de notre très profond filial respect".

34 Lettres de Marc Sangnier à Monseigneur Campistron, évêque d'Annecy, texto impreso, ASV Segr.Stato 12 (1901) 14 28-30.

35 "Le Sillon et Marc Sangnier. Notes Confidentielles", sin fecha, pero antes de 1910, ASV Fondo Benigni 8 1084a 420-421. 
Un primer dato es que no se conocía la organización real del movimiento. Era imposible asegurar la disciplina y entusiasmo con los elementos visibles que se agrupaban en torno a Marc Sangnier. La organización era dirigida por unas 50 personas, 12 de ellas en París. Esta doble estructura dirigente había sido ya denunciada por Flavien Brenier en 1909 y por Ariès en su obra sobre Le Sillon.

El enlace con Societé d'Éducation Morale era Vanderpol, portavoz de la tesis de la masonería. En su conflicto con el catolicismo, todas las culpas eran para la Iglesia. Vanderpol daba conferencias en los círculos sillonnistes.

A través de su relación con Paul Couillard, vinculado a los ambientes ocultistas, protegió a Marc Sangnier e intervino en su evolución personal, La Ligue Française Antimaçonnique establecía una conexión de Le Sillon con el modernismo judío y el ocultismo. ${ }^{36}$

Marc Sangnier es un iluminado, un líder. Se siente investido de la misión de sacar de sus dificultades a la Iglesia de Francia y conducirla, superando todos los peligros, hasta su meta. Debe recordarse que "Le Sillon est essentiellement un mouvement religieux". En su mística desbordante se halla la raíz de su fascinación.

Es normal que, con esos rasgos y con un jefe como Marc Sangnier, Le Sillon choque con la jerarquía celosa de sus prerrogativas, Para preservar de cualquier intromisión externa y de otras influencias, incluso internas, a Le Sillon, Marc Sangnier no apeló abiertamente a la autonomía. Eso supondría expresarse como un liberal furioso. Se manifiesta como un católico respetuoso con la jerarquía, que únicamente usa la libertad en la política, donde Iglesia lo permite a sus fieles.

Por eso Le Sillon se presenta como un movimiento laico y político. Fue católico y "demócrata" en sus publicaciones y en sus actos políticos. De ese modo nadie puede reprocharle un "libéralisme doctrinal", porque no rechaza la autoridad de la Iglesia. ¿Ha sido lícito ese cambio? No, porque Le Sillon fue y sigue siendo un movimiento que conserva su carácter moral y religioso.

Basta examinar la actuación de los sillonnistes. En todo siguen la dirección de Marc Sangnier, dejando al obispo las normas de culto pero controlando las obras católicas, que se orientan en beneficio del movimiento.

Los obispos son conscientes de la situación, pero no toman medidas porque todas las apariencias ocultan lo que, de hecho, está pasando. En ese contexto se sitúa la constante llamada de Marc Sangnier a que le descubran sus errores para poderlos enmendar. Es un gesto en el vacío. Incluso la prohibición de que los eclesiásticos participen en el movimiento favorece el dominio de Marc Sangnier sobre los sillonnistes. Nadie puede negar la calidad moral y religiosa de estos, pero creen que las quejas contra ellos forman parte de una persecución injusta.

¿Es así? No lo parece. Llama la atención a quienes conocen Le Sillon que sus miembros carezcan de una conciencia católica. Sus lecturas, además de la Biblia, son Pascal, Lacordaire, Gratry. Péreyve... excluyendo a los que se consideran "profundamente católicos y romanos". Su imagen de Cristo es idéntica a la de un protestante devoto. Su devoción a la Eucaristía se vive como una fusión con JesúsHostia, que les ilumina directamente.

Jamás hablan de la Virgen. La única excepción fue la intervención de Marc Sangnier en el Congreso Mariano de Roma, en diciembre de 1904, cincuentenario

36 "Note sur le Sillon", sin fecha, pero posterior a 1909, ASV Fondo Benigni 6799 154-159. Sobre las relaciones entre Le Sillon y el iluminismo esotérico, "Marc Sangnier, le Sillon et l'illuminisme ésotérique. Notes confidentielles", junio 1910, Ibídem: 844 256-258 y 1088b 425-530. 
de la declaración dogmática de la Inmaculada Concepción. Su espiritualidad recuerda el misticismo de II Santo y los misterios de "le petit Sillon" recuerdan las catacumbas y los "caballeros del Espíritu Santo" que aparecen en la novela de Fogazzaro.

Para los sillonnistes la Iglesia es vista como la Sinagoga en tiempos de los primeros cristianos. Le Sillon como el cenáculo. Aunque los apóstoles y los discípulos no dejaron de acudir al Templo, no abandonaron la comunidad del pueblo de Dios, en el cenáculo florecían la piedad y la gracia que anunciaban los tiempos nuevos. Allí recibieron el Espíritu para salir a la conquista del mundo.

¿Es eficaz la condena? No. Se someterá de inmediato. Invitará a los suyos a que lo hagan, pero continuará su labor, porque Marc Sangnier no tiene una doctrina, sino un liderazgo. Lo peligroso no es que sea un partido. Le Sillon es una secta. No se trata de poner dificultades a un partido republicano ni a un organizador de obras democráticas, sino de cerrar el paso a un profeta iluminado, que tiende a dominar a la autoridad de la Iglesia. ${ }^{37}$ Es una tarea paciente. Necesita mucho tiempo. Habrá que convencer a los sillonnistes que la Iglesia no ataca sus ideas, ni censura sus opiniones. Se defiende de modo legítimo frente a la presión de un iluminado que hay que desenmascarar. ${ }^{38}$

\section{UNIONS DIOCESAINES Y LIBERTAD PARA LOS CATÓLICOS EN POLIITICA}

En 1910 se produjo un giro importante en la situación de los católicos en Francia. El arzobispo de París, Léon F. Amette. prohibió el centenario de Montalembert. La Croix defendía las Unions Diocésaines. La Ligues Patriotiques des Femmes Françaises y Jacques Piou se manifestaban intransigentes y ya no hablaban de "libertades religiosas" ni de situarse en el terreno constitucional.

La parte frágil de esta rectificación estaba en todos los intereses creados, que podrían convertir esta nueva postura en un mero oportunismo.

Por eso los intransigentes juzgaban necesario establecer claramente las posiciones. La Union Libérale Populaire no estaba en la dirección trazada por Pío $X$. Había que decirlo con claridad. Su fracaso político la privada de su pretensión de ser la ejecutora de las instrucciones de la Santa Sede. Dentro de ella, se consideraba a Piou una persona imprescindible, pero era ambigua su distinción entre medios ciudadanos y medios políticos. Porque no dejaba despejada su actitud ante las instituciones republicanas y ante las leyes que las sostenían.

Por otra parte. en muchos de los congresos diocesanos para poner en marcha las Uniones, había predominado la tendencia democrática, al menos en el plano social y económico. En el campo electoral dominaba la Union Libérale Populaire. Debían además estas uniones librarse de la tutela de La Croix. No sería fácil

${ }^{37}$ Sobre este aspecto, "Marc Sangnier, Le Sillon et l'llluminisme esoterique. Nots confidentielles", Paris junio 1910, ASV Fondo Benigni 8 1084b 425-430. Parece que Benigni juzgaba insuficiente este enfoque fundado en presunciones y no en hechos. Hay una nota manuscrita que alude a la campaña de Flavien Brenier en 1913 en la Revue Antimaçonnique, editada en París, Ibídem: 1084c 431.

38 "Le Sillon y Marc Sangnier. Notes confidentielles", sin fecha, ASV Fondo Benigni $81084^{a}$ 418-421 y " La Résurrection de la Gnose et l'Idéalisme Démocratique. Gnose et Démocratie », sin fecha, Ibídem: 81097 469-483. Hay unas observaciones que rebajan la importancia que se da a la figura de Marc Sangnier, porque su prestigio ha sufrido descalabros entre los que han sido sus cooperadores, Ibídem: 422-424. 
superar la situación dentro del movimiento social. Los "Sillons Catholiques" y la Association de la Jeuneuse Catholique de France, eran tambien demócratas.

Habría que insistir en la labor de reforma cristiana, dejando a un lado los resultados electorales. Para obtenerlos en lo social y en lo religioso, urgía acentuar la nota católica y la intransigencia. La interferencia política, la necesidad de dedicarse a las elecciones, perjudicaría a las obras sociales obreras. Había sucedido ya en Bélgica. La mezcla no beneficiaba la formación cristiana de los miembros de esas asociaciones.

Las Uniones iban a librar de la politización por parte de la Action Française a los católicos. Este primado de la política -"politique d'abord"- las inhabilitaba para ser un sitio donde recalen los católicos para intervenir en política. El gran problema del catolicismo francés es haber tenido, desde hacía treinta años, como dirigentes políticos, a personas "muy académicas", de palabras corteses y elocuentes, pero liberales. Querían convencer y hablaban a la razón.

Para ganar elecciones hay que excitar la pasión, tal como hacían los sectarios, que llamaban al odio, a la envidia... Los católicos debían despertar contra sus adversarios cólera, indignación, asco. Había que usar un lenguaje violento para poder persuadir y ganar votos. ${ }^{39}$

Aunque en Francia las elecciones son limpias, la Action Française se abstiene. Sabe que su programa va más allá de lo que puede entender y aceptar el electorado. Si lo adaptara, perdería fuerza "l'affirmation de la vérité politique".

Esta intransigencia le ganaba el favor de la juventud y de la parte más sana de la sociedad. Habían sabido separar de la causa monárquica todo lo que había en ella de parlamentario y académico. Desde esta perspectiva, estaban de más las Unions Diocesaines. ${ }^{40}$ Su tarea debía ser la lucha ideológica, es decir, el combate contra el liberalismo, el democratismo, el modernismo, en todas sus versiones. El camino era aún largo. ${ }^{41}$

El mejor modelo podría ser el que funcionaba en Toulouse. Laicos trabajando como ciudadanos en el orden civil y político, sabiendo que este no se reduce a las elecciones, sino que se extiende a la escuela, la prensa y las obras sociales.

El clero se dedica a las asociaciones, cuyo fin es la piedad y la formación cristiana. La unidad la asegura la adhesión al arzobispo. Así no se mezcla en política y la organización no aparece como "le parti des curés". 42 Se pueden elegir dirigentes eficaces, aunque no sean los más dóciles. La acogida sera mayor entre los católicos que luchan por su Iglesia sin ser devotos.

39 El horizonte que presentaba este informante, el $\mathrm{C}$, era la creación de un estado de violencia. Si los católicos obtuvieran en 1914 una mayoría que no fuera posible en la Cámara destruirla mediante la discusión de actas, el presidente de la República, con la ayuda del Senado, la disolvería. Habría nuevas elecciones. Si ganaran otra vez los católicos, entonces declararía en peligro la república. $Y$ entonces los diputados electos tendrían que apelar a la fuerza para salvar sus derechos. Pues tal decisión de no pararse ante la violencia, si esta es necesaria, debería quedar patente ante los electores para que se animaran a participar, seguros de que su voto no era inútil.

40 Jamás podrían tener ese tipo de oradores y de dirigentes resueltos. Desde este análisis, la situación de Francia era de guerra civil en gestación. Era la hora de los soldados y generales. Al clero le bastaba con enseñar los principios, que den fuerza y valor a ese ejército.

${ }^{41}$ En Francia sólo la Action Française difundía las publicaciones de Delassus, Barbier, Fontaine, Correspondence de Rome. Sólo ella siente la necesidad de destruir el espíritu liberal. Las otras aún están impregnadas de liberalismo.

${ }^{42}$ La exclusión del clero parece a uno de los informantes, un rasgo de liberalismo. Importa que en las Unions estén laicos y sacerdotes. Y que trabajen juntos. 
Desde el punto de vista organizativo quedaba pendiente la coordinación entre todas las Unions Diocésaines. ${ }^{43}$

La posición del cardenal Secretario de Estado de Pío X no se alejaba tanto de la que sostuvo León XIII en relación con Francia. En una entrevista Rafael Merry del Val dijo a Theillier de Poncheville: La Action Française hace bien en no pedir la bendición de la Santa Sede, porque se le negaría. "Aucun groupement catholique ne peut agir contre la Constitution".

Aunque se aseguraba que los cardenales Vives i Tutó y Domenico Ferrara eran partidarios de Le Sillon, la posición firme se formulaba así: "liberté complète... aux catholiques sur le terrain politique, sans désapprouver nullement l'Action Libérale qui n'a rien à changer, sans patronner nullement d'autres groupes". Los obispos deben dejar de actuar como jefes políticos. "Pas de parti catholique". "Vous ne trouveriez pas dans les Actes du Saint-Siège un mot d'encouragement à aucun groupe monarchique". ${ }^{44}$

Bajo la cobertura de Le Sillon el modernismo penetraba especialmente entre los jóvenes. Lo denuncia el obispo de Beauvais, Noyon et Senlis el 10 de febrero. Decían que eran mal comprendidos. Pero no era verdad. Erraban en su concepción de una obediencia meramente externa, destinada a salvar las apariencias y eludir las consecuencias desagradables de las medidas de la autoridad. Era una "hipocresía formal". ${ }^{45}$ Osaban atribuirse haber descubierto en el Evangelio lo que está en todas partes de su texto: el amor al prójimo, la entrega a su servicio, la caridad hacia todos sin importar la clase a la que pertenezcan.

Cumpliendo las normas emanadas de la Santa Sede se prohibía a los seminaristas recibir, guardar, leer o escuchar la lectura de un escrito "sillonnistes", colaborar con Le Sillon, la publicación del movimiento, redactar una revista "sillonniste" para intercambio entre ellos, tener círculos o hacer reuniones de varios en el seminario o fuera de él, durante el recreo o en los paseos o en cualquier otro momento de la jornada para hacer propaganda "sillonniste" en una palabra, realizar cualquier acto que signifique adhesión a Le Sillon.

Los superiores del seminario tenían obligación de informar al obispo de cualquier transgresión de norma. Nadie puede ser ministro de la Iglesia contra la Iglesia o a pesar de la Iglesia. El movimiento "sillonniste" es subversivo, niega la sumisión interior a la autoridad... En la Iglesia todo se debe hacer a plena luz. ${ }^{46}$

43 "Constatations et problèmes sur la vie religieuse en France de 1910", ASV Fondo Benigni 223057 224-233. La preservación de los católicos inspira este documento, al que se asocia las opiniones de otras tres personas, una de ellas muy favorable a la Action Française.

44 "Notes de M. Theillier de Pocheville après ses conversations avec le Cardinal Merry del Val", enero 1910, ASV Fondo Benigni 676022.

${ }^{45}$ Fue este un aspecto destacado por sus enemigos. "Le Sillon se croit hors d'atteinte à cause du vague de son programme t de ses affirmation contradictoires. II se réserve de dire toujours qu'on ne l'a pas compris e qui l'on préte des idées contraires aux siennes. Mais le cardinal Andrieux vient de lui citer des théses qu'il ne peut les desavouer tant il les répéte souvent". Charles MaignenMerry del Val o Vives y Tutó, Tournai, 5 avril 1910, ASV SS 12 (1910) 14 109. La contribución de Charles Maignen con sus escritos en la condena del americanismo el 22 de enero de 1899. N. Ariès, Le Sillon et le mouvement démocratique, Paris 1910, 24.

${ }^{46}$ Lettre de la 'Éveque de Beauvais, Noyon et Senlis a M. Le Supérieur du Grand Séminaire de Beauvais portant la défense de lire les écrits du Sillon ou d'adhérer de quelque manière que ce soit au Sillon, 12 fevrier 1910, texto en ASV Segr.Stato 12 (1910) 14 93-94. 
Cuando apareció el libro de Monniot, con la respuesta de los obispos a su encuesta para La Libre Parole, ${ }^{47}$ en el diario de la Santa Sede, su director dijo que el episcopado francés había condenado Le Sillon. El obispo de Niza, Henri Chapon, escribió el 11 de enero de 1910 al director de L'Osservatore Romano. Desmentía ese dato. La mitad de los prelados no respondió. De los que lo hicieron, sólo unos diez se manifestaron en contra. Había enviado un escrito confidencial a sus colegas. Casi todos ellos se adherían al análisis que se hacía sobre el movimiento. Incluso los que tenían objeciones, pedían que no fuera condenado. ${ }^{48}$

El arzobispo de Rouen, Edmond Frédéric Fuzet advirtió a Chapon sobre el artículo de L'Osservatore Romano. Para frenar la campaña, sugería al obispo de Niza que redactara una carta y la enviara a la firma de todos los obispos. ${ }^{49} \mathrm{Se}$ había manipulando las expresiones del Papa, ${ }^{50}$ creando en torno a los "sillonnistes" un ambiente de sospecha y viendo en ellos a falsos hermanos modernistas y afines al protestantismo. Pero "ex fructibus eorum cognoscetis eos", dice el Evangelio. Las obras de los "sillonnistes" eran buenas. ${ }^{51}$

Se trataba de buscar una protección similar a la que tuvieron los "Labour's Knigts" norteamericanos en el cardenal James Gibbons. En las afirmaciones de Marc Sangnier no había nada condenable. Aunque los obispos tenían motivos para preocuparse, no debe hacerse un proceso de intenciones. El problema era el giro hacia una asociación meramente laica, ${ }^{52}$ sin que los "sillonnistes" midieran el alcance de ese cambio, dada su confianza en el jefe.

Entre el clero joven había calado esa imagen de una resurrección católica de Francia. Había una nota preocupante. Los seminaristas consideraban que la piedad, tan profundamente arraigada entre los "sillonnistes" laicos, era cosa de "clericalismo".

Se sospechaba también de la relación de Marc Sangnier y de su movimiento con quienes no eran católicos. ¿Se preocupaban de mantener la integridad de la fe?

${ }^{47}$ La encuesta fue publicada bajo el título Le Sillon, Lettres épiscopales, s.f., 27 pp. texto impreso, Ibídem: 18/2. No hay que confundirla con como Le Sillon. Lettres Épiscopales que recogía las cartas aparecidas en una sección de L'Éveil Démocratique, en abril de 1910.

48 "Je serais étonné que ces Évêques, dont plusieurs sont éminants pour leur zèle et la jalouse intégrité de leur doctrine, aient en si peu de temps, changé d'avis". Carta sin fecha, de la que se da noticia en la carta de Chapon a un obispo, 11 enero de 1910, copias mecanografiadas, Ibídem: 17 74-76.

${ }^{49}$ Fuzet-Chapon, 14 de enero de 1901, Ibídem: 73.

${ }^{50}$ Como ejemplo el uso que hizo el obispo de Beauvais en su súplica al Papa firmada el 7 de marzo. Había dicho Pío X al obispo de Bayonne, F.-M. Gieure: "Viam sequuntur dammnosam", pero había añadido un consejo: sea bueno con esos jóvenes: son sinceros y generosos", Ibídem: 19 y 71.

${ }^{51}$ Por eso "il faudrait les encourager, les protèger, les bénir de toutes nos âmes, ces intrépides jeunes apôtres, sauf à guider leur inexpérinece et corriger les innocentes audaces". F. Guillibert, obispo de Frejus, 25 de enero de 1910, Ibídem: 70-72.

${ }_{52}$ Pío X mostró a Marc Sagnier que no compartía ese giro. "Tu deficisti,...voluisti associationem mere laicam". Esta afirmación la reproduce el obispo de Beuavais en la súplica al Papa, ya citada. Vid. el testimonio el obispo de Bayonne. En la audeiencia con motivo de la visita ad Limina, el Papa dijo a Mgr F.-M.Gieure: "viam sequuntur damnosam".Emmanuel Barbier, La décadence du "Sillon". Histoire documentaire (2), Paris 1907, 21-22. 
Todas estas dudas y críticas no podían ocultar que Le Sillon supuso "ce réveil de la jeuneusse française", del que daba testimonio el cardenal arzobispo de Lyon, Pierre-Hector Couillié. ${ }^{53}$

Marc Sangnier expuso el 10 de febrero de 1910 al arzobispo de Albi, EudoxeIrenée Mignot las dificultades de Le Sillon. Este le respondió el 3 de marzo. Era una carta muy matizada y hasta crítica. Al aparecer como la primera de las que recibieron en el semanario, pudo entenderse como un apoyo. Mignot dudaba de la lealtad de los "sillonnistes" a la Iglesia. Estaba seguro de que la Santa Sede hablaría y todos, unánimemente, obedecerán.

En primer lugar había que hacer justicia a sus intenciones generosas. Habían roto los prejuicios que existían entre catolicismo y la República. Habían quebrado el anticlericalismo, que se servía de una especie de monopolio democrático. Y habían destruido esa deplorable asociación del anticlericalismo que unía progreso social e irreligión. Lo habían hecho con corazón limpio y lleno de amor a Cristo.

$\mathrm{Ni}$ las condenas de algunos obispos ni el deseo de que los sacerdotes no manifestaran preferencias por alguna organización cristiana suponían una desaprobación. Rendía justicia a Le Sillon, porque había sabido romper los prejuicios de los republicanos contra la Iglesia, quebrar el monopolio democrático del anticlericalismo y terminar con esa asociación de ideas que unía el progreso social con la irreligión.

La Iglesia no podría arrojar sombras sobre ese esfuerzo que, con generosidad y abnegación, había vuelto a irradiar la influencia social del cristianismo. Si se desautorizara a los sillonnistes, las masas populares durante mucho tiempo creerían que existe incompatibilidad entre República y catolicismo.

Ante las acusaciones contra ellos, les aconsejaba seguir la regla de San Ignacio de Loyola: un cristiano, ante una proposición oscura del prójimo, debe estar más dispuesto a justificarla que a condenarla. Si no puede hacerlo, debe pedir que se la explique y, si, hecho esto, no puede aceptarla, debe corregirlo con amor. Si eso no basta, debe buscar finalmente los medios que ayuden al prójimo a volver a la verdad y a la salvación.

Como obispo, Mignot no juzgaba las teorías económicas y políticas de los sillonnistes, sino su conducta como católicos. ${ }^{54}$ Desde esta perspectiva consideraba que eran buenos por su fe, su moral y su disciplina. Tenía la impresión el arzobispo de Albi de que las imputaciones venían de la política y se encubrían con la apariencia de vigilancia religiosa. "Cette manœuvre est infiniment préjudiciable non seulement au Sillon, mais à l'Église, qu'elle tendrait à compromettre". La unión entre los católicos ha de respetar la libertad para debatir sobre cuestiones económicas y políticas.

Afirmaban con valor sus convicciones religiosas y ganaban para la Iglesia nuevas simpatías. Centrando su trabajo en el orden temporal, podrían herir "dans leur idéal social quelques espérances trop lointaines". Con todo, si las quejas contra Le Sillon prosperaran y lograran su desautorización, ese acto "accréditarait pour longtemps dans les masses populaires la conviction néfaste de l'incompatibilité du catholicisme avec la forme actuelle du gouvernement".

53 Pierre Couillié-Merry del Val, 8 de marzo de 1910, ASV Segr.Stato 12 (1910) 17 66-67.

54 "Avant de condamner des hommes, avat même de les décourager, de les diqualifier, de les meurtrir douloureusement par des vagues sopçons, il faudrai formuler leurs torts d'une façon precise". 
Nemo reputatur malus nisi probetur. Ese principio exigía que las acusaciones fueran precisas. En cuanto a la fe y a la moral, aceptaban la autoridad de la Iglesia y vivían conforme a ellas, dando testimonio público de su condición de católicos. Y aceptaban la dirección de la Iglesia en la proyección pública del catolicismo. No podría desconocer que muchas de las acusaciones y ataques a Le Sillon procedían de fines políticos enmascarados con motivos religiosos. ${ }^{55}$

El arzobispo de Albi, Eudoxe-Irénée Mignot envió a los obispos el documento,"Mémoire sur le Sillon". ${ }^{6}$ Era la respuesta de los "sillonnistes" a las preguntas sobre su fe y su obediencia a la autoridad eclesiástica. Lo hacían "sans réticences, disposés à supprimer, à changer et à corriger" todo lo que no estuviera conforme al espíritu de la Iglesia.

En el terreno político eran republicanos y demócratas. Su elección se fundaba en la experiencia de los cambios de sistema político habidos en Francia durante un siglo. El régimen vigente era una caricatura de lo que ellos deseaban. República y democracia tal como la tradición católica permite entender los dos términos. Los republicanos católicos tendrían que aportar su concurso necesario para que la república respetara la tradición católica de la nación y los derechos de los católicos. Los católicos de oposición no traerán esa república. Y los republicanos sectarios la harán contra el catolicismo. Le Sillon tiende a formar, dentro de la sociedad, una elite consciente de sus deberes y responsabilidades cívicas.

Nadie podría censurar las ideas sociales, más teóricas que prácticas, de Le Sillon. Pío X les había dicho que era su derecho pensar en esos asuntos con plena libertad. Las dificultades con algunos obispos venían de la presencia del clero en los círculos y en las actividades de los "sillonnistes". ${ }^{57}$

¿Qué era "le Grand Sillon"? Lo integraban los católicos que, sin compartir todas sus ideas, lo favorecían porque lo juzgaban una obra útil. Entraban en él también los republicanos no católicos que, respetando la libertad de conciencia, tiene simpatía por los "sillonnistes". En modo alguno era el fruto de concesiones, como se había dicho desde hacía varios meses. Demostraba la incorporación, al menos parcial, de estos no católicos a un ideal respetuoso con el catolicismo.

Habían entrado en la acción política, necesaria para rectificar errores e instaurar progresivamente un régimen que respetara todos los derechos, comenzando por los de la religión. Esta acción política se entendida como perfeccionamiento de la vida ciudadana, no como competencia para controlar el poder. Se integraba en ese proceso de educación cívica, propio de Le Sillon. Por

55 Le Sillon, Lettres épiscopales, s.f., 3-7, texto impreso, Ibídem: 18/2 55. Le Sillon no lesionaba ese principio, pues lo reclamaba para los suyos: sinceridad religiosa y libertad política, Copia sin fecha, Ibídem: 17 149-155 y Le Sillon, Lettres épiscopales, con las cartas del arzobispo de Albi, a quien escribieron el arzobispo de Rouen, y los obispos de La Rochelle, Clermont y Nice. El de Versailles lo hizo directamente a Marc Sangnier. Un ejemplar, Ibídem: 14 111. Explicó el 14 de mayo el obispo de La Rochelle al cardenal Merry del Val el motivo de su carta a Mignot, Ibídem: $133 .$.

56 Texto impreso sin firma y sin fecha, dos ejemplares, Ibídem: $18 / 2$ 58-59 y 62-65.

57 El arzobispo de Rouen apoyaba la defensa que el obispo de Niza hacía de "ces braves jeunes gents sillonnistes, qui rendent à l'Eglise le grand service de faire pénétrer l'idée religieuse dans la démocratie ouvrière et paysanne... Leurs chimères economiques s'evanouiront aux leçons de l'experience et au contact des réalités de la vie: les fruits de leur apostolat demeureront" Fredéric Fuzet-Mignot, 10 mars 1910, Le Sillon, Lettres épiscopales, s.f., 8-9, texto impreso, Ibídem: 18/2 55 y "Partie documentaire. L'Épiscopat et le "Sillon" », Chronique de la Presse 496 (Paris 31 mars 1910) 184. 
tener ese objetivo, ${ }^{58}$ se situaba en el terreno social y político y desarrollaba una acción que se realiza fuera del ámbito de competencias de la Iglesia, que nunca ha de enfeudarse en una opción política.

En el orden espiritual, los "sillonnistes" son, como buenos católicos, hijos sumisos de la Iglesia En cuestiones mixtas, sostenían que el interés espiritual debía prevalecer y corresponde a la Iglesia pronunciarse. En el orden político, no aceptan ni un forma de poder ni una legislación que contradiga las normas de la Iglesia sobre justicia y moral. En la acción social, de un alcance más amplio que la política, se conforman, como todos los fieles, a los principios trazados por la Iglesia. Le Sillon no profesa ideas religiosas propias. Sus publicaciones jamás acogieron las teorías modernistas, sino que las reprueban.

Se ve, por tanto, que se somete a la dirección inmediata, alta dirección, o control de la Iglesia en todas las circunstancias en que ella lo exige. En cuanto a esto último, tres obligaciones:

1. No proponer ni aprobar nada que sea contraria a las prescripciones de la Iglesia para asegurar el respeto de la justicia, de la moral y de la religión;

2. no recurrir al secreto para eludir ese control, sino obrar a plena luz y

3. Obedecer a la Iglesia cuando, en el ejercicio de esa alta dirección o control, exige rectificar un error contra las verdades morales y religiosas de las que ella es guardiana.

"La liberté civique des catholiques sur le terrain temporel ne consiste donc pas à décider sans se préoccuper de l'Église; mais uniquement à choisir eux-mêmes parmi les diverses solutions conformes aux principes dont l'Église a la garde la solution qui leur paraît préférable".

Reconociendo la situación especial de Italia, los "sillonnistes" creían que sus libertades ciudadanas no quedaban disminuidas por su condición de católicos. El compromiso político es un incentivo para vivir con mayor intensidad la fe. Ella les sostiene en la dura labor que han escogido. Muchos de ellos son cristianos ejemplares de los que cada año salen vocaciones para los seminarios y para la vida religiosa.

En su formación religiosa siguen los caminos que la Iglesia ha aprobado. No tienen un método propio.

"Les sillonnistes ne demandent au prêtre (parfois royaliste) de les faire bons républicains, mais ils sollicitent son secours pour devenir de bons chrétiens".

Cuando piden estar bajo el derecho común de los fieles manifiestan su voluntad de obedecer todas las indicaciones de la Iglesia. No pedían a los obispos que los cubrieran de sus responsabilidades en el terreno cívico. Lo dijo Marc Sangnier a Pío X en septiembre de 1904: no le solicitamos una preferencia de Su Santidad por nuestros métodos y que conforme de forma formal nuestra confianza en el futuro de la democracia en Francia.

58 "... promouvoir la république démocratique et pour cela créer en France des convictions, des attitudes, des institutions véritablement républicaines et démocratiques". 
Los "sillonnistes" creen que su acción política debe continuar bajo el control de la jerarquía, no bajo su dirección inmediata. Y, al mismo tiempo lamentarían que los obispos los ignoraran, porque quieren ser vistos por ellos como "sillonnistes" y como católicos. En su último congreso se comprometieron a participar en las obras parroquiales y diocesanas como católicos. $Y$ siempre han querido contar con la ayuda de un sacerdote, porque como "sillonnistes" saben que su acción en el terreno político tiene una dimensión religiosa. Y que su compromiso es para ellos una experiencia espiritual.

Esta era su posición, pero Mignot no pudo mantenerla. ${ }^{59}$

\section{"UN AMPLIO CAMPO DE LIBRE DEBATE"}

El obispo de Niza, respetando las decisiones de algunos otros contra los "sillonnistes" y aceptando imprecisiones en su lenguaje y excesos e imprudencia, recordaba que hay que tolerar eso en los jóvenes, si son de conducta irreprochable y no se quería asfixiar en ellos "toute iniciative et tout élan".

Se declaraban hijos de la Iglesia. Acudían a los sacerdotes. Vivían una fe ardiente y de ella daban testimonio ante los otros, sobre todo entre las clases populares. Muchos se habían convertido a través de esa acción de Le Sillon. Habían testimoniado su fe en reuniones públicas y respondiendo a las interpelaciones de sus adversarios.

Se les reprochaban más sus ideas sociales que las políticas. En su ideal de una república democrática y cristiana había algunas quimeras. Quienes los descalificaban por eso olvidaban o desconocían cómo son los jóvenes, sin embargo, los sillonnistes no se obstinaban en sus posiciones y estaban dispuestos a rectificar.

Se les acusaba de varios errores. ${ }^{60}$ Se les llamaba socialistas por denunciar las carencias de un sistema social que sacrificaba a la clase obrera. Había que transformarlo para poder satisfacer las necesidades de los trabajadores. León XIII había dicho que la mayoría de los obreros vivían en una miseria injusta. Le Sillon no quería establecer la justicia en favor de la clase obrera sacrificando la propiedad privada ni por medio de una revolución violenta, sino por una evolución "laborieuse et progressive, elle-même conditionnée par l'éducation morale et chrétienne".

El éxito dependía de la cooperación de los mismos interesados y de las resistencias de la realidad económica, a la que deberían adaptarse las iniciativas individuales y colectivas, "pour ne pas entrer dans la voie révolutionnaire". Se buscaba la transformación por el crecimiento pacífico y legítimo de la propiedad colectiva, por la sustitución de los patronos por parte de los sindicatos y por la participación de los asalariados en los beneficios. En política también eran irreprochables sus principios. Les gustaba gritar, con frecuencia, ¡Viva la República! Nadie podía prohibirlo.

Henri Chapon decía que no había hallado en los escritos y discursos de los "sillonnistes" nada que pudiera acusarlos de modernistas o liberales. En el origen

${ }^{59}$ El 22 de abril, después de haber recibido la carta del arzobispo de Lyon, cardenal Pierre Couillié, escribía Mignot al Papa dejando las cosas en su sitio. Limitó el alcance de su carta a Sangnier, pero publicó la que le envió Couillié, olvidando que era un ecrito confidencial. Mignot-Pie X, 22 avril 1910, ASV Segr.Stato 12 (1910) 14 125-126.

60 "Plus une accusation est grave plus elle doit être précise... Or j'ai été toujours frappé des accusations portées contre le Sillon et de leur insaisissable généralité et imprécision". Carta de "I'un de nos plus vénérabes et savants archévêques". 
de las críticas a Le Sillon se hallaba una confusión. Sus adversarios ignoraban que, fuera de las cuestiones de fe y moral definidas por la Iglesia y de aquellas directamente ligadas con ellas, existía un amplio campo de libre debate entre los católicos, como en 1885 había afirmado León XIII en su Inmortale Dei. Es cierto que la Iglesia podría fijar los límites de ese pluralismo. Pero también lo era que los "sillonnistes" aceptaban esa facultad de la jerarquía. Los que tenían autoridad para acusarles de apartarse de estos principios deberían concretar en qué y cómo, pues "on ne pas hérétique ou schismatique malgré soi". Muchos parecían olvidar el axioma in dubiis libertas. ${ }^{61}$

Si se siguiera el criterio de los que así piensan contra esto, se extinguiría entre los católicos la iniciativa, el valor y la energía para realizar proyectos. Y su lugar lo ocuparían el miedo y la inercia. Los católicos no podrían aportar nada a los problemas complejos de la sociedad o actuarían siempre comprometiendo a la jerarquía.

Se les tachaba de cooperar con no católicos. Nadie podía negar el fervor de los "sillonnistes". Jamás habían mezclado las cuestiones religiosas en las acciones en las que participaban no católicos. León XIII y Pío X habían aconsejado la unidad de los católicos y de las personas honestas en política y en la acción social. Había que sostenerlos en los riesgos que asumían, sin entrar en los compromisos que libremente asumían.

Una decisión contra Le Sillon no convertiría a sus seguidores en rebeldes a la Iglesia, pero los desalentaría. Las obras católicas perderían unos activos colaboradores. Nadie sustituiría su presencia en medio del pueblo. La Jeuneuse Catholique, la otra organización, hacía su tarea en claves conservadoras. Era necesaria, pero insuficiente. Los "sillonnistes", en cambio, tenían un espíritu de conquista. Habían entrado entre los trabajadores y comenzaban a hacerlo entre los intelectuales, dos ambientes hasta entonces cerrados a los católicos. ${ }^{62}$

El 28 de marzo remitió Henri Chapon a varios obispos franceses una extensa memoria confidencial, enviada luego al Papa "avec une filiale liberté". Le Sillon era la mejor y casi, podría decirse, la única esperanza de la Iglesia en Francia. Bastantes obispos deseaban que fuera condenado por la Santa Sede. Estaban en su diócesis de Nice. Los conocía de cerca. En conciencia tenía que declarar que no merecían los reproches de sus adversarios. Su condena sería un desastre. No se rebelarían, pero vendría un largo período de desaliento, de iniciativas abortadas, y la sensación de que era mejor la pasividad y una "prudencia egoísta". La condena

61 Esta frase, citada a veces de modo más amplio, In necessariis unitas, in dubiis libertas, in omnibus caritas, aparece casi literalmente en un texto del obispo de Split, Marco Antonio de Domini, De republica ecclesiastica libri X, editado en Londres en 1617, liber IV, cap. 8. Quitada la peste de la abominación en la Iglesia, "omnesque mutuam amplecteremur unitatem in necessariis, in non necessariis libertatem, omnibus caritatem. Ita sentio, ita opto, ita plane spero, in eo qui est spes nostra et non confundemur". Nellen H. J. M. 1999. "De zinspreuk 'In necessariis unitas, in non necessariis libertas, in utrisque caritas,"' Nederlands archief voor kerkgeschidenis 79/1: 99-106.

62 Partidario del recurso al Santo Oficio, estaba seguro de la imparcialidad de la Santa Sede y de la obediencia de los "sillonnistes". "L'Épiscopat et "Le Sillon". Nouvelles Lettres épiscopales. Lettre de Mgr. Chapon, évêque de Nice » L'Éveil Démocratique 182 (27 mars 1910) 1-2 y Le Sillon, Lettres épiscopales...s.f., 8-9, texto impreso, ASV SS 12 (1910) 18/2 55 (pp. 16-25) y "Partie documentaire. L'Épiscopat et le Sillon”, Chronique de la Presse 496 (Paris 31 mars 1910) 185-186.. 
se consideraría una victoria de L'Action Française, que habían instigado la campaña contra Le Sillon. Reiteraba lo publicado en L'Éveil Démocratique.

¿Cómo vivían su pertenencia a Le Sillon los seminaristas franceses? Hasta hacía poco la diócesis de Beauvais se vio libre del contagio "sillonniste", que sufrían las de Amiens y Soissons. A través de ellas y con ocasión del servicio militar, las cosas habían cambiado. Pese a la oposición de los superiores, se había hallado el cuaderno de un diácono, Emile Fournet, originario de la diócesis de Amiens, que había creado un núcleo de "sillonnistes". En él escribía sus impresiones y sus colaboraciones en el revista clandestina que circulaba por el seminario. Algunas de sus páginas fueron presentadas por el obispo como piezas de acusación contra los "sillonnistes". 64

En ellas se sostenía que la misa pontifical es para burgueses a los que gusta la celebración presidida el obispo, apta para gentes de internado y orfelinatos educados en una religiosidad externa. Los obreros no acuden a ella. Se lo impide el cansancio y la necesidad de hacer en sus casas la faena que dejan para los días de fiesta. ¿Qué significa para ellos estas bellas catedrales? El sitio donde acuden curas y devotos con una cartera injustamente llena. ¿Cuándo podrá el obispo celebrar su misa en medio de un pueblo reconciliado y fraterno? Francia será de nuevo cristiana cuando la Iglesia se haga pueblo, es decir todo para todos.

Le Sillon proporciona una experiencia espiritual centrada en el amor al prójimo. Supone, pues, una crisis con esa piedad egoísta y burguesa, en la que se formaba a los seminaristas. Había también una fascinación por Marc Sangnier. Muchos curas hablaban de cosas, que los otros escuchan como ajenas a quien las pronuncia. Marc Sangnier es un testigo. Su palabra acredita lo que es. Su secreto, la entrega total a Dios y a sus semejantes. Un "sillonniste" vive para los demás, y, actuando así, los eleva y educa. De ese modo vence el respeto humano y todo temor y obra como un apóstol.

Hay que revelar a cada cual lo que hay dentro de sí. Aquello que, en su interior, aparece inexplorado y que representa las mejores aspiraciones del ser humano. La audacia de un testigo se inspira en la caridad, por eso ni avasalla ni violenta al prójimo. Busca su bien, no la victoria de quien se cree dueño de la verdad que anuncia.

Frente al autoritarismo, conciencia y responsabilidad, que hay que despertar en cada uno y guardando la obediencia y la sumisión del propio criterio sólo a la fe y a la Iglesia. Habría que interpretar el perinde ac cadaver. ${ }^{65}$ Los "sillonnistes" quieren colaborar con quien manda y dirige, sin prescindir de su inteligencia y de su

63 Henri Chapon-Pío X, 22 de junio?, ASV Segr.Stato 12 (1910) 14 60-71 y copia mecanografiada, 72-83. La memoria confidencial fue enviada antes a más de cuarenta obispos, la mayoría de ellos, compartían este escrito. Una copia de este documento, Ibídem: 17 77-85 como anexo a la carta de Chapon al director de L'Osservatore Romano, desmintiendo que el episcopado fracés hubiera condendo a Le Sillon. Una copia con la firma de Henri Chapon, 28 mars 1909, ASV Segr.Stato 12 (1910) 17 341-347. Copia mimeografiada, s.f., Ibídem: 149-155.

${ }^{64}$ Este cuaderno, con extracto del diario de un seminarista y de algunos artículos escritos para la revista clandestina que circulaba entre los "sillonistes", fue enviado por el obispo de Beauvais, Jean C. Douais, el 7 de marzo. En el seminario había 8 "sillonistes", ASV Segr.Stato 12 (1910) 17 43, 22-64 y 7. Las fechas, desde noviembre de 1909 hasta el 9 de febrero de 1910.

65 Esa fórmula convertía en ideal la obediencia ciega. Pero lo mejor era que tanto el que manda como el que obedece vean. Eso significa no que quien obedece conozca todas las razones, pero que tenga alguna para hacer lo que en ese momento se le ordena, aunque sea la confianza en el superior. 
corazón. Esa obediencia activa nada tiene que ver con esa retórica que tiene siempre en los labios: "la voluntad de Dios". Hay que saber reflexionar y dar razones. Este nuevo estilo tiene que partir de los jóvenes. No se podía contar con los notables para mejorar la sociedad.

"L'oeuvre de Le Sillon consiste à donner à ceux, intellectuels ou travailleurs, qui en sont capables une âme de dirigeants, c'est à dire, un tempérement qui leur permettra de travailler non pour eux mais pour les autres, d'être assez désintéressés pour accepter la collaboboration de tous les citoyens".

Cristo vino a subvertir las ideas y convenciones del viejo mundo pagano. Necesita a los cristianos para proseguir esa acción en el siglo XX.

"Nous avons le désir nous autres, pauvres fils d'ouvriers qui manquons d'argent et d'appui, de bouleverser le monde pour rétablir la Justice et l'Amour".

Sería locura emprenderlo sin dejar que Cristo crezca a diario en cada uno. Había que dejarse enseñar por quienes fueron delante por el camino del progreso y del futuro. La Iglesia tiene la verdad, pero "ne croyons pas surtout que tel vieux bonze est la règle vivante de l'orthodoxie rigoureuse!".

Hay una tendencia en el espíritu humano de disminuir la verdad, es decir de pasar del espíritu a la letra, de Dios, que es la verdad, al ídolo que es la tradición humana. Estas palabras del oratoriano Joseph Alphonse Gratry, y el reglamento que regula la vida del seminario desde hacía más de 60 años, llevan a preguntar qué resta de un Dios, que es "espíritu de renovación". A tiempos nuevos, mentalidad nueva. Otra vez Gratry: el espíritu de Dios suscita santos nuevos que no necesitan repetir lo que hicieron los de otros tiempos. Pero en el seminario les pedían reproducir el pasado. ${ }^{66}$

Un buen "sillonniste" no tenía que lamentarse por la mentalidad de sus superiores y quejarse de la hostilidad y de la indiferencia de otros sacerdotes. A cada uno le bastaba cumplir su deber. El amor al prójimo exige ser sobrio en la búsqueda de satisfacciones. Esa era la clave para optar por la educación popular, una labor humilde sin la cual nada tiene consistencia. No había que resignarse, pero sí aceptar lo humilde y alegrarse de ello.

En el seminario los "sillonnistes" vivían bajo sospecha y casi en clandestinidad. ${ }^{67} \mathrm{Su}$ adhesión al movimiento sólo estaba subordinada a la decisión de la Iglesia, no al deseo autoritario de los superiores o del director espiritual. No podrían descubrir su ideal a curas clericales, incapaces de salir de sí mismos y de abrirse a las nuevas realidades. Ante los dogmáticos ultras, silencio, pero con respeto y sin agresividad. A quienes ponen obstáculos, agradecerles la ocasión de perdonar. Para poder hacer había que conocer las razones de la incomprensión y de la persecución de los adversarios, un amor más fuerte que el odio. Es también

\footnotetext{
${ }^{66}$ Entre los "sillonnistes" "il est compris depuis longtemps que les Français désirent une Républiue large, ouverte à tous, passionnée par la Justice et l'Amour".

67 Siendo una minoría en el seminario, trataban de seguir su camino y de responder una llamada interior. "Nous ne sommes pas des émeutiers mais, à l'exemple du Christ, de révolutionnaires", Ibídem: 57.
} 
más inteligente y luminoso. La primera tarea de un "sillonniste" es la adaptación del catolicismo a los tiempos nuevos. No había que perder el tiempo. ${ }^{68}$

\section{"INSPIRARSE EN AQUELLOS QUE HAY QUE EVANGELIZAR"}

El 7 de marzo de 1910, Jean C. Douais, obispo de Beauvais, presentó, en forma de súplica al Papa, una acusación formal contra Le Sillon. ${ }^{69}$ Con sentimientos generosos y de amor y entrega a los más pequeños y humildes, es decir, por la clase obrera, apuestan por la democracia y contra la burguesía y la nobleza. Iluminados por su fe en Jesucristo, hacen un apostolado activo en ambientes hostiles a la Iglesia. Rejuvenecen las formas de anunciar el evangelio y crean nuevas formas de acción.

Su objetivo es que triunfe el amor frente al odio. Pero, de hecho, caen en la lucha de clases frente a la burguesía y a la nobleza. Entre el clero consideran a los sacerdotes mayores desadaptados e incapaces para trabajar en la educación del pueblo.

En cuanto a sus ideas, atribuyen a la democracia un valor absoluto en el terreno social y político. Aunque excluyendo de esa exigencia a la Iglesia, quieren reformarla, poniendo como eje su democratización. En sus relaciones con la autoridad ponen en primer término las exigencias de la acción. Hablan del derecho a colaborar con ella.

Si se llegara a condenar a Le Sillon, guardarían silencio. Obedecerían externamente, dejando que pasara el tiempo. Es el bien común el que justifica las decisiones de la autoridad. Por eso desde ese principio, hay que creer en una especie e armonía preestablecida que se restablecerá con el paso del tiempo. Sólo hace falta esperar. La obediencia es un asunto de disciplina.

Su modelo de sacerdote nada tiene que ver con la tradición. Se inspira en los ambientes sociales que hay que evangelizar. Desconocen que la voz de Dios llega a través de la tradición de la Iglesia. Por eso se sienten llamados a salvarla y aspiran a reformarla. ${ }^{70}$

Su distinción entre sacerdote y ciudadanos supone aceptar la división de la conciencia cristiana. Por ese camino acaban negando al cristiano y a la Iglesia, como tal, el derecho de conocer las doctrinas económicas y políticas y de someterlas a su juicio a la luz de la revelación y de la Palabra de Dios.

Se sienten revolucionarios y ven a Cristo como un revolucionario. No consienten una corrección. Se refugian en un subjetivismo místico. No se ven más que a sí mismos, con el pretexto de entrega a los demás. Señal de ese enclaustramiento es el uso de un lenguaje propio. Eran como una masonería.

Aunque había palabras del Papa que mostraban su desconfianza ante la orientación de Marc Sangnier y de Le Sillon, se necesitaba una postura más clara de condena. "Il faut leur opposer un document sans réplique, qui dirime ce conflict et fasse loi".

El obispo de Dijon, Pierre Dadolle, lamentó que cerca de unos cincuenta obispos hubieran respondido a la encuesta de La Libre Parole. Se trataba de un

${ }^{68}$ Las contradicciones entre la organización del seminario y el ideal que presentaba Le Sillon, Ibídem: $36-39$ y 45-47. El seminario como una prisión, 17 décembre 1909. En él se vivía entre muros y encadenados, antes de las vacaciones de Navidad, Ibídem: 42, 55 y 58.

${ }_{69}^{6}$ Les agissements du Sillon, 7 mars 1910, Ibídem: 17 11-19.

${ }^{70}$ Las páginas del cuaderno del diácono Fournet, cuando hablan de autoridad y tradición "sont pure folie". 
asunto doctrinal. $Y$ ese no ERA cauce adecuado para que se expresaran los obispos. Eso originó una especie de "Ligue Épiscopale" para la defensa de Le Sillon. Habían editado un memorial, el de Mignot, que circulaba por las diócesis. En él se probaba que el movimiento ni era herético ni cismático $\mathrm{y}$, por eso, tenía derecho a actuar libremente.

Había un gran acto de justicia en esta afirmación, sobre todo mirando hacia atrás. Los jóvenes "sillonnistes" son los que más se esfuerzan en acomodar su vida con la fe. Habían revitalizado la Jeuneusse Catholique. La habían hecho un grupo activo. Sin ellos continuará siendo "une confrérie fermée". Cuando se les acusaba, respondían sometiéndose y pidiendo con todo respeto que se les señalara los puntos precisos que tenían que corregir.

¿Qué aspectos eran discutibles? Su objetivo de construir una democracia verdadera, que quieren que sea cristiana. Para lograrlo reivindican su independencia en el terreno político y "social" (arts. 1 y 2 de sus Estatutos). Lo primero es legítimo. Lo segundo no, pues los principios de la sociología son un capítulo de la moral.

El papel del sacerdote en los grupos "sillonnistes" es formar cristianamente a quienes van a realizar su objetivo político y social, pero se les dispensa de la acción política. Esta distinción entre la dirección espiritual y la dirección política es arriesgada. Porque no funciona en el plano práctico. Todos verán en un sacerdote comprometido en la vida de Le Sillon a un partidario de la democracia Con ello perderá su independencia como sacerdote.

Si Le Sillon defiende su autonomía, los obispos, que necesitan para las obras católicas jóvenes vinculados a su autoridad, tratarán de que no se inscriban en su movimiento.

No había que inquietar públicamente a Le Sillon. Los obispos, con alguna queja, deberían advertir a los "sillonnistes" de su diócesis. Urge mantener la neutralidad política de la Iglesia y, como un gesto que lo demuestre, que los sacerdotes no participen en organizaciones que sean políticas. ${ }^{71}$

Las disensiones en torno a Le Sillon moverían a la Santa Sede a tomar una decisión en un plazo corto. ${ }^{72}$ Obispos cercanos y favorables a los "sillonnistes" y a Marc Sangnier le habían ya solicitado que ni los condenara ni los censurara. Otros insistían en que hubiera cuanto antes una reprobación formal y absoluta. Quería el Cardenal Merry del Val conocer el criterio de algunos obispos.

"Il m'a paru nécessaire, après entente avec le Saint Pére de demander leur pensée personnelle à quelques évêques connus pour leur rectitude doctrinale et leur pondération d'esprit".

Se les solicitaba su opinión sobre Le Sillon desde el punto de vista de las ideas religiosas, de la actitud hacia la autoridad episcopal, las aproximaciones a los

71 "Una condemnation globale aurait probablement le danger de paraître atteindre l'idée même du mouvemenet démocratique, cher au Sillon, et à d'autres. II importe au contraire que ce mouvement paraisse permis, pourvu qu'on ne fasse à personne une obligation d'y entrer". Pierre Dadolle-Merry del Val, 14 mars 1910, ASV Segr.Stato 12 (1910) 17 3-6. En esta misma carta, el obispode Dijon considera ajeno a la realidad planificar la acción de la Iglesia partiendo de la idea de que la mayoría de los franceses es católica.

72 "Actes Officiels du Saint-Siège et de l'Épiscopat défavorables au "Sillon", Chronique de la Presse 496 (Paris 31 mars 1910) 186-190. 
partidos políticos, las ventajas e inconvenientes de la Jeneusse Catholique de enfeudarse en el movimiento y las refutaciones o explicaciones que los "sillonnistes" dan a las acusaciones que se les hacen. Se pedía que, en sus conclusiones, cada obispo se pronunciara sobre la oportunidad de condenar Le Sillon y L'Éveil Démocratique. ${ }^{73}$

El 10 de marzo de 1910, en la clausura del IX Congreso Nacional de Le Sillon, Marc Sangnier habló de una república nueva. No le venía mal al sistema republicano tener una oposición monárquica. Los "sillonnistes" rechazaban a quienes estaban introduciendo en el corazón mismo de la república costumbres contrarias al espíritu republicano, es decir, a los que deseaban transformarla en una tiranía en beneficio de la banda de la que formaban parte. Eran aquellos que, con el pretexto de defenderla, la acaparaban, la encadenaban, la despreciaban y la degradaban.

La República era un sistema difícil de realizar. Exigía que cada ciudadano, además de ocuparse de sus asuntos personales, familiares y profesionales, lo hiciera también de los de la nación. Era un sistema que llamaba a cada persona a ampliar el círculo de sus responsabilidades morales y cívicas. Así se convertía en una alternativa a la anarquía.

Había una historia que se remontaba hasta 1789. Entonces creyeron que la monarquía desaparecía guillotinando al rey y dejando vivo el espíritu que inspiraba las instituciones. Fracasó luego la República de 1848, a pesar del talento de Alphonse de Lamartine, que cortó sus alas morales al sectarismo de los revolucionarios. Vino luego la derrota de 1870 y aquella república, que debería dar paso a una restauración monárquica, se consolidó y se transformó en un proyecto nacional, que habría que sostener a pesar de todas las dificultades.

Los "sillonnistes" Ilamaban a todos los hombres a construirla, por encima de sus diferencias de ideas y creencias, con tal que se respeten las fuerzas morales, sin las cuales el proyecto fracasaría. Se había recorrido un camino equivocado desde 1880. La escuela laica de Jules Ferry era deísta. Luego dejó de serlo. Los que ocupaban el poder lo habían convertido en un arma de lucha contra la religión y la moral, contra el ideal cristiano y espiritual de Francia.

¿Que pretendía Le Sillon? ¿Armonizar la teocracia pontificia y la declaración de los derechos del ciudadano? ¿Una República de curas? No. Afirmaban que la República no podía incluir entre sus señas de identidad la lucha contra el catolicismo y contra la Iglesia. Se creía que un católico no podía ser un buen republicano. De ese modo los republicanos anticlericales se unían a los reaccionarios, que también gritaban eso.

Muchos pensaban que la República no podía ser republicana, si no estaba abierta a todos los ciudadanos dispuestos a trabajar por el bien público y si no respetaba las fuerzas morales que los católicos encontraban en su entrega a Jesucristo. La República debía estar abierta a todas las convicciones religiosas y a todas las visiones del mundo. Deberían competir así para demostrar que, en las suyas propias, cada uno halla razones y nuevas fuerzas para trabajar por el bien común.

${ }^{73} 42851$ Sub secreto pontificio, Merry del Val-Louis Péchenad, obispo de Soissons, I. Sevin, obispo de Châlons, Henri-Joseph Bougouin, obispo de Périgueux, Albert Négre, obispo de Tulle. El documento firmado por el cardenal el 15 de marzo, no fue enviado. ASV Segr.Stato 12 (1910) 14 8487. 
Nadie debería extrañarse al oír que Le Sillon está fundado por católicos sinceros, resueltos a sacrificarlo todo para permanecer unidos a la Iglesia de Jesucristo. Los habían atacado por ser católicos y, por eso, poco fiables. Habían alertado contra él a los fieles. Esto les había herido, aunque desde el punto de vista político pudiera considerarse una ventaja, pues desmentía a quienes los tachaban de clericales.

En Le Sillon no hay ideas religiosas propias, sino sólo las de la Iglesia. Aceptaban su disciplina en todo lo que ella quiere ser obedecida, incluido el terreno social y político, donde siempre hay una dimensión moral. Porque la moral no es ajena a ninguna realidad humana, la Iglesia no es una extraña cuando interviene en los problemas sociales. Esta convicción la habían proclamado incluso en los ambientes más hostiles.

Este discurso tenía una base ética: decir la verdad. Había también en esa conducta la afirmación de que los católicos tienen los mismos derechos que los demás ciudadanos. No tienen, pues, que esconder su condición de tales. $Y$ en Francia había un motivo más. La Santa Sede había dicho que todos los católicos, más allá de sus opciones políticas, tenían el deber de "de travailler à réaliser dans leur pays l'organisation politique et social qui convient mieux à ce pays lui-même". Con esa orientación, no estarían aislados. Junto a los "sillonnistes" estaban los hombres honestos. Forjar esa unidad cívica era un deber que tenían como franceses.

El partido católico, el catolicismo político, sí que distorsionaba la constitución de la Iglesia. Los católicos no tendrían que obedecer al Papa y a los obispos, sino ponerse a las órdenes de políticos y de periodistas.

A Le Sillon habían acudido personas que juzgaban que la República y la democracia necesitaban un fermento moral, e incluso cristiano. Algunos de ellos recordaban que el ideal republicano estaba ya en los inicios del cristianismo primitivo. Tenían presentes la inspiración cristiana de las primeras asambleas de 1789 y que en 1848 los sacerdotes bendijeron, en las plazas de Francia, los árboles de la libertad. Había muchos "qui se souviennent surtout que c'est exactement dans la mesure où l'idéal chrétien s'est séparé de l'idél républicain que la république est devenue triste, malfaissante et inféconde".

Frente al sectarismo asfixiante, era preciso buscar todo lo que une, permite el encuentro y refuerza a todos. Hacer una política de afirmaciones, que crea y no destruye, integra y no margina. ${ }^{74}$ Hay que merecer el futuro. Hay que ganarlo con trabajos y perseverar en ellos con esperanza, haciendo de ella un conjuro frente a la sensación de que todo va mal.

"Nous savons bien que la France sera ce que les Français la ferons; nous nous sentons assez de courage, assez d'amour pour briser la haine et pour ramener la France à la tête des nations dans la voie de justice et de fraternité où elle entraînera encore l'humanité". ${ }^{75}$

\footnotetext{
${ }^{74}$ Marc Sangnier se dirigió a los masones presentes y les pidió: "Détruisons ce sectarisme, ce clericalisme qui déshonore la République actuelle".

75 "Discours prononcé par Marc Sangnier au Cirque de Rouen, le dimanche 20 mars 1910", Supplément à l'Éveil Démocratique de 27 mars 1910, 4 pp.. En este mismo número, crónica el Congreso que tuvo lugar los días 17-20 de marzo, Ibídem: 3-4.
} 
Hippolyte Gayraud, el sacerdote diputado por Brest, no simpatizaba con Marc Sangnier, pero creía que los obispos defendían Le Sillon, porque su experiencia del movimiento era buena. En sus diócesis los sillonnistes trabajaban bien y deseaban cubrirlos frente a los ataques de sus adversarios.

Convencido de la buena voluntad de Aristide Briand en su deseo de arreglar la situación con la Iglesia, ${ }^{76}$ no percibía Gayraud que la carta y la encuesta sobre Le Sillon fueran para algunos prelados una manera de mostrar su oposición a Roma. ${ }^{77}$

Gayraud, el sacerdote diputado, estuvo en una cena con algunos sacerdotes de París. Se asustó de su modernismo, Les dijo que, si pensara como ellos, haría ya tiempo que habría abandonado la sotana. Su débil base, que aún les permite cumplir en conciencia sus deberes como sacerdotes, no basta para que puedan enfrentarse a otras obligaciones. ${ }^{78}$

A favor de Le Sillon estaban los obispos de Albi, Rouen, Nice y Versailles. Estos se habían ganado a los de Fréjus, Clermont, La Rochelle y alguno más. El de Fréjus, Felix Guillbert, abogaría ante la Santa Sede adelantándose a una posible condena. ${ }^{79}$

La peor acusación que podía hacerse a Le Sillon era la de ser desleal manipulando la realidad y la verdad. ${ }^{80}$ A esa maniobra se refirió el obispo de Nancy et Toul, poniendo como ejemplo la respuesta dada a los errores señalados por los obispos que respondieron a la encuesta de Monniot en La Libre Parole. Recoger textos de discursos y de escritos de Marc Sangnier era una burla. Pues, en cualquiera de ellos, pueden hallarse verdades. Era tan desleal como lo fue el jansenismo. $^{81}$

Bastaba como ejemplo la división que los "sillonnistes" introducen en las obras católicas. Las palabras de Marc Sangnier nada probaban contra la decisión del Congreso de Le Sillon en l'Epinal rehusando la unión con los conservadores, a quienes llamaban los enemigos internos más peligrosos que tiene el catolicismo. "Le Sillon crée parmi les catholiques de France, dejà si divisés, de lamentables divisions". ${ }^{82}$

76 Tenía esa misma opinión el obispo de Mónaco, Jean Charles Arnal de Curel. Lo comentó con Gabriel Hanotaux, ex ministro de Asuntos Exteriores. "France. Hanotaux", 22 marzo 1910, ASV Fondo Benigni 6808174.

77 "On y voit l'explotation d'une opposition longtemps contenue à l'enseignement et aux actes de Pie X". Los obispos, a quienes exaspera la línea del Papa, buscan en Le Sillon una base para mantener su resistencia, "France. Sillon", 22 marzo 1910, Ibídem: 811177.

78 "France. Eléctions, situation religieuse", 12 abril 1910, Ibidem: 839249.

79 "France", 21 y 20 y 22 marzo 1910, Ibídem: 806-811 172-178.

80 Le Sillon et les erreurs contemporains, Paris, s.d., 26 pp. Hay dos ejemplares en ASV Segr.Stato 12 (1910) 1433 y 34

${ }^{81}$ Como ejemplo el obispo de Nancy cita, al final de su escrito, a Mémoire sur le Sillon, que acababa de aparecer. Sin firma, afirmando ahora la sumisión a la Iglesia después de haber dicho cientos de veces, en los últimos años que eran una asociación política no católica. En ella no se halla autocrítica sobre sus ideas, sus métodos, su actos. "Le Sillon a été parfait et l'est encore".

82 Bastaba examinar su prensa. En lugar de limitarse a defender la República democrática, informar sobre la realidad social, empujar a su lectores a una entrega mayor en favor de las clases populares, "il ajoute una campagne incessante de détraction, soit direcement, soit par insinuation, contre les meilleurs el les plus dévoues défensers de la cause catholique". Carta de François Dalamaire, arzobispo coadjutor de Cambrai, publicada en L'Univers, 17-18 juillet 1907, y recogida en Barbier, Emmanuel. 1907: 38-52, texto citado, 48. 


\section{SE AMPLÍA EL DEBATE}

A la defensa que el arzobispo de Albi hizo del movimiento, habría que hacerle estas observaciones. Frente a quienes dicen que los "sillonnistes" son generosos, hay que decir que Marc Sangnier es orgulloso y ambicioso. Chocó con Jacques Piou porque no permitió que un diputado veterano de Action Libérale le cediese su puesto. Era un déspota que no soportaba críticas, ni de los de abajo ni de sus iguales.

El arzobispo decía que nada había condenable en las doctrinas políticas y sociales. Eso sería verdad, si criticar el patriotismo y apoyar el socialismo fueran cosas discutibles para un católico. Había una larga lista de errores, señalados con numerosos textos en varias ocasiones. ${ }^{83}$ Los "sillonnistes" habían aplaudido a los sacerdotes Dabry, Naudet y Lemire. Eran alabados por protestantes, socialistas y librepensadores. ${ }^{84}$ Nadie los acusaba por ser republicanos.

Era evidente que Le Sillon no iba por el camino de la obediencia a la autoridad de la Iglesia. Había predicado la anarquía a los obreros; a los hijos, la rebelión contra los padres..$^{85}$ Había que condenarlo. ${ }^{86}$

Tenemos noticia de la reacción del cardenal arzobispo de Burdeos a la Memoire de Eudoxe-Irénée Mignot. Le Sillon había planteado cuestiones que León XIII había tratado en sus encíclicas: relaciones entre natural y sobrenatural, libertad y autoridad, sociedad civil y sociedad religiosa; la naturaleza de la política, de la economía y de la diplomacia, límites de la ciencia y de la acción popular cristina...

La respuesta de Mignot a Pierre Paulin Andrieu, arzobispo de Bourdeaux, decía Louis Billot el 1 de abril, suponía una gran capacidad de síntesis o un estilo superficial. Mignot, en relación a Le Sillon, defendía estos dos principios: unidad de los católicos gracias a la sumisión a la Iglesia en materia de fe y moral, y plena libertad de acción en el terreno de la política, de la economía y de la ciencia.

La acción popular cristiana se movía en una esfera diferente a la de la política y la economía, aunque no puede decirse que estén separadas entre sí. Esta dificultad para establecer unos conceptos claros sería un rasgo netamente modernista y esa apelación a haber sido mal comprendidos les servía de excusa. Pero la encíclica Pascendi Dominici Gregis era muy clara: son modernistas quienes desean excluir a la Iglesia de la política y, al mismo tiempo, le piden que se adapte para infundir su espíritu en las instituciones civiles.

${ }^{83}$ Turinaz remitía a su folleto, Les périls de la foi et de la discipline, editado en 1903. Se denuncianaba como errores dogmáticos, extendidos en Francia, la llamada democracia cristiana, el americanismo, el loysismo, la apologética de la inmanencia, errores sobre Jesucristo, la Iglesia, la Reforma, el Concilio de Trento, las congregaciones religiosas, la libertad de enseñanza...

84 Esta acusación, en una carta sin firma, dirigida al Papa desde París el 18 de marzo: "Si le Sillon est approuvé, nous craignons bien que ce ne soit que le triomphe de tous les modernistes que l'entourent de leur sympathie", ASV Segr.Stato 12 (1910) 14 89-90

${ }^{85}$ Una forma de aproximarse a todos sus errores, los escritos de Barbier, Emmanuel 1906. Les idées du Sillon, Les démocrates chrétiens et le modenrisme, Les erreurs du Sillon, La décadence du Sillon. Y era muy valioso el libro de Th. Delmont, Modernisme et modernistes en Italie, en Allemagne, en Anglaterre et en France. Paris: Letheillieux, éditeur - Lyon: A. Nouvellet, Éditeur.

86 "J'ai étudié, sans parti-pris, les publications du Sillon et ses actes depuis vingt ans, et ma conviction absolue est qu'une condemnation solennelle de cette association est nécessaire et urgente". Repetía, en texto manuscrito y con mayor energía, esto mismo a final de su carta al cardenal Merry del Val(?), 22 mar 1910, ASV Segr.Stato 12 (1910) 17 68-69.

87 Una descalificación de la postura del arzobispo de Albi, en el informe de Louis Billot, "Sur Le Sillon", Rome 1 avril 1910, Ibídem: 257. Lo considera bajo este epígrafe: "Cicero pro domo sua". 
Esta imprecisión se prolonga en la identidad de Le Sillon como una amistad. Por eso no es un grupo, ni un partido, ni una cofradía, ni una obra católica. No necesita jerarquías. El movimiento es una comunidad de pensamiento, pero sin decir cuál sea éste.

Su acción busca enseñar a vivir mejor, a perfeccionarse y preparar el advenimiento de la verdadera República Democrática. Por eso declaran que su labor se desarrolla en el Estado, no en a Iglesia. Tienen derecho a la libertad para hacer su propaganda. Era esta situación la evolución normal de jóvenes que después de quince años se sentían adultos. Por se motivo, Mignot reclamaba que vivan bajo "le droit commun", expresión totalmente imprecisa. ${ }^{88}$

Le Sillon defendía la revolución, con el agravante de enmascarar con la religión ese objetivo y de decir que protegía así mejor la verdadera expresión del cristianismo. Con estas palabras arranca el informe del jesuita Louis Billot para responder a la pregunta de la Santa Sede sobre la conveniencia de condenar a Marc Sangnier y a sus seguidores

El clericalismo que Le Sillon combate tiene un sentido diferente al que le dio en 1880 Léon Gambetta. Clerical es quien utiliza las leyes y la violencia para imponer convicciones religiosas. Supone confundir los dos poderes, utilizando la violencia del poder civil para conseguir la aceptación de dogmas o de verdades de orden intelectual, moral o religioso. Ese clericalismo no ha existido jamás. Por eso se supone que, con ese lenguaje, condena la cooperación del poder civil con la Iglesia, proposición incluida como errónea por Pío IX en la Quanta cura y en la proposición 24 del Syllabus.

Le Sillon es un "champion de l'erreur libérale". Utiliza todos los lugares comunes que emplean también los revolucionarios para criticar a la Iglesia y descalificar las instituciones de la "monarquía cristiana".

La democracia de Le Sillon no es la democracia cristiana definida por León XIII en la Graves de communi. ${ }^{89}$ Marc Sangnier dice que no busca la "democracia cristiana", sino la "democracia social", es decir, la que proporciona el gozo de los bienes terrenales. La convierte en el bien supremo al que subordina la religión. Desde la justicia y la fraternidad se define a Dios.

Es dudoso que ese proyecto político mantenga la diferencia de clases y salvaguarde la propiedad privada. Al examinar el lenguaje empleado en Limoges, Billot asegura que es idéntico al de Jean Jaurès y al de todos lo socialistas. En él se expresan el individualismo de la revolución y el igualitarismo del contrato social. Marc Sangnier sostiene que, sobre estos asuntos, la Iglesia no debe pronunciarse. La conclusión era que

${ }^{88}$ El autor de estas notas, que podrían, según el mismo, llamarse "Réflexion d'un séminariste après la lecture de la réponse de Mgr. Mignot au cardinal Andrieu". El seminarista, André Leroux, era además doctor en derecho por la universidad de París. Y no temía comparar el lenguaje del arzobispo de París con el de Albert Léon Le Nordez, obispo de Dijon, a quien el papa exigió la dimisión. "... la lettre de Monsegneur d'Albi n'est pas seulment une oeuvre de vanité prétentieuse et superficielle: c'est un acte d'indiscipline d'une exceptionnelle gravité". ASV Segr.Stato 12 (1910) 17 214-217.

Roma 1902 3-20. 
"le fanatisme révolutionnaire qui l'anime, (est) le moyen le plus efficace pour implanter le modernisme dans l'âme de la jeuneusse, et plus particulièrement de la jeuneusse cléricale".

Todos los modernistas se sentían identificados con Le Sillon, que, a su vez, era la realización de los ideales de Antonio Fogazzaro. La clave de su éxito reside en la apariencia de evangelismo con que se presentan. Son ideas generosas y brillantes revestidas de misticismo religioso. Jesús fue el primero y el mayor de los grandes revolucionarios. La democracia era una causa sagrada.

En el terreno moral Le Sillon es el "americanismo". Nada de virtudes pasivas para los ciudadanos conscientes y responsables. Hay la misma tendencia a sentirse en un tiempo nuevo que no reconoce la tradición, que no tiene precedentes. En cuanto a la disciplina, hay una contradicción entre el ideal democrático, que supone una organización desde abajo, y el de la autoridad, que viene de arriba. Por eso no querían que los clérigos dirigieran el movimiento. No podía haber disciplina donde todos son camaradas. ${ }^{90}$

Publicado Le Sillon, esprit et méthodes, ${ }^{91}$ de Marc Sangnier, el obispo de Tulle, Albert Nègre, lo examinó atentamente. Había que hacer lo mismo con todos los escritos de Marc Sangnier fundador y alma de Le Sillon. Creía ver en ese texto ideas falsas sobre moral y religión y sobre las relaciones de los seglares con los obispos. No estaban enunciadas "explicitis verbis". El libro abundaba en insinuaciones y afirmaciones engañosas. Muchos sacerdotes y una parte del episcopado consideraban el movimiento exento de errores filosóficos y teológicos.

Se equivocaban y estaban perdiendo su autoridad y su prestigio los obispos que así pensaban. Sus cartas en favor de los "sillonnistes"92 eran como una acusación a otros obispos y la Santa Sede, que, según decían, habían sembrado la desconfianza hacia ellos sin precisar acusación doctrinal alguna.

Le Sillon aparece como una federación de grupos. Es un movimiento y un "alma común". ${ }^{93}$ Es una vida, ${ }^{94}$ un proyecto que necesitaba de una elite, que define como una "majorité dynamique", formada por una fuerza moral más que por el número.

Querían poner al servicio de la democracia las fuerzas sociales que se hallaban en lo que llama el cristianismo social. La democracia es la organización que tiende a llevar a su más alto grado la conciencia y la responsabilidad cívicas de cada persona. Ese objetivo y esa inspiración hacen de Le Sillon una obra moral, religiosa y católica. $\mathrm{Y}$ estas tres dimensiones penetran todas las actividades y toda

90 Sur Le Sillon, Rome 1 avril 1910, ASV Segr.Stato 12 (1910) 17 253-258. Analiza sobre todo el discurso de Marc Sagnier en el Congreso de Limoges, noviembre de 1907.

91 Paris: au "Sillon", (s. d.)

92 Se refiere a "L'Épiscopat et "Le Sillon". Nouvelles Lettres épiscopales", una sección de L'Éveil Démocratique, editada luego como Le Sillon. Lettres Épiscopales.

${ }^{93}$ Cuando Marc Sangnier estuvo en Limoges, en 1903, y propuso al grupo de jóvenes que trabajaban con Jean Desgranges incorporarse a Le Sillon, les dijo que no se obligaban a nada: "car (il) est une amitié. On en fait partie lors qu'on veut bien prier et travailler avec nous... nos ignorons chez nous les règlements, les contraintes administratives et les dirigeants". Desgranges, Jean. 1909: 10.

94 "La Sillon est une vie... Nous pouvons le définir comme l'effort d'une génération vers la démocratie sous l'impulse fraternelle de l'amour du Christ". 
la estructura del movimiento. ${ }^{95}$ Esto le sitúa en una relación directa con la Iglesia. Cree que el catolicismo es una religión revelada. Que la Iglesia es infalible al enseñar los dogmas y la moral. Tiene una jerarquía a la que los "sillonnistes" obedecen.

Al llegar a este punto, el obispo de Tulle, Albert Nègre, subraya que ellos no son simples fieles, pues se comprometen a enseñar la doctrina de la Iglesia. Eso les hace depender de la jerarquía de una forma especial, es decir, directamente. $Y$ aquí estaba el error del libro. No podía ser Le Sillon, como sostenía en él Marc Sangnier, una instancia independiente de los obispos, con autonomía de acción, como entidad civil. ${ }^{96}$ Eso negaba su condición de "obra religiosa".

Además de esta cuestión central, había en el libro una serie de "assertions censurables". Una de ellas, que el Papa aprueba la autonomía de Le Sillon. Lo era afirmar que la Jeuneusse Catholique era una organización cerrada, sin influencia entre los jóvenes. Al citar la identidad de modos entre el movimiento "sillonniste" y el discurso de Ferdinand Buisson, nada rectifica en cuanto al libre-pensamiento" y a eso que el mismo Buisson llama "métodos emancipadores". El tono del escrito respira iluminismo y presunción.

Estos eran motivos suficientes para condenar el libro. Desde 1905 nada había cambiado en la metodología y en el temario de los grupos "sillonnistes". Existía la convicción de que los libros y discursos de Marc Sangnier nada tenían contrario a la doctrina de a Iglesia. Si la Santa Sede, tras las apelaciones hechas esos días, no los condenaba, serían leídos con mayor confianza y eso lesionaría la autoridad de muchos de los obispos de Francia que los desaprueban.

El iluminismo de Marc Sangnier era su punto débil. Habían comenzado a abandonarlo algunos de sus amigos. Más que un elenco de errores, habría que descubrir el que estaba a la base de todos ellos, "le démocratisme". No podría negar Sangnier que era partidario de la democracia. La había convertido en una especie de nuevo milenarismo, el final necesario de veinte siglos de cristianismo. "La constitution essentiellement monarchique de l'Église se trouve indirectement atteinte para ces éloges enthousiastes de l'idéal démocratique". No quería hablar de ese aspecto y trataban de "democratizar" la Iglesia. Detrás de esa inspiración democrática estaba la influencia judía de la masonería. Los masones decían "el Mesías es la revolución". El democratismo sillonniste era la revolución. ${ }^{97}$

Los rasgos que configuran la imagen de Le Sillon lo presentan como una empresa de educación popular y social; un movimiento moral y, por tanto, religioso y u partido político. Fundado y dirigido por católicos, agrupa a católicos fervientes. Pero, según afirman ellos mismos, es un movimiento laico autónomo, no

95 Para Marc Sangnier, "le Sillon est donné...comme un mouvement essentiellement religieux, comme une école avant tout religieuse, dont l'élite enseigne la morale religieuse et sociale d'une manière active. Suivant son but, elle emprunte à la doctrine catholique les forces sociales qu'elle y trouve et s'en sert pour former jusqu'au maximum la conscience et la responsabilité civiques de chaque citoyen de la democratie", ASV Segr.Stato 12 (1910) 17199.

${ }^{96}$ Según Marc Sangnier la situación de Le Sillon de cara a la Iglesia es "exactement la situation du pouvoir temporel chrétien en face du pouvoir spirituel écclésiastique", Ibídem: 202.

97 "La censure de ce "messianisme démocratique" aurait plus l'avantage d'atteindre tous ceux qui professent la même doctrine sans appaternir au Sillon". Documento sin firma ni fecha, pero calificado como una nota "fort bien faite et temoigne d'une connaissance du caractère de Marc Sangnier et du genre d'action qu'il exerce sur les jeunes gens et sur certains prêtres ou séminaristes", Ibídem: 17 212-213. Albert Nègre-Merry del Val, 10 de abril de 1910, Ibídem: 14 116117. 
confesional. Al dirigir a sus miembros a un apostolado social y moral, les en ellos, junto a su condición de católicos, "une mentalité complémentaire". No tenía otra salida para superar la ambigüedad y evitar la confusión que declararse un movimiento verdaderamente laico en sus fines y métodos. Debían hacerlo los "sillonnistes" para que no se apagara esa corriente de vitalidad que ellos aportaban a la Iglesia y a la sociedad francesa. ${ }^{98}$

Ese último rasgo lo miraban con ironía sus amigos. Bastaba escuchar a Marc Sangnier. Pero lo preocupante era la imagen de secta que ofrecían los "sillonnistes". Se les notaba en su pretensión de ser los primeros y los mejores. No era verdad. Pues antes de Le Sillon y antes de que naciera Marc Sangnier hubo iniciativas audaces y fecundas entre los católicos. Muchos de ellos ya eran tolerantes e inteligentes y podría contemplarse el futuro de la República en otro modelo diferente que el seductor, pero frágil, creado por Marc Sangnier. ${ }^{99}$

El papa deseaba que el cardenal de Lyon comunicara a todos los obispos que estaban interviniendo en favor de Le Sillon que guardaran silencio. Las polémicas entre ellos causaban una mala impresión. Existía el recurso de acudir a Roma, donde se examinaría cuidadosamente todas las informaciones que enviaran. Por el momento, Pío X se limitaba a recomendar al clero, sobre todo a los sacerdotes jóvenes, que se mantuvieran al margen del movimiento "sillonnistes". ${ }^{100}$

Intervino La Croix en el debate. El objetivo de Le Sillon es la educación popular para poder cristianizar la democracia. Su acción se desenvuelve en el campo de la acción popular cristiana querida por León XIII y Pío X. ${ }^{101}$ Se declara sumiso a la Iglesia y, al mismo tiempo, celoso de su autonomía. Esta se da en el terreno político, aquella en la esfera social.

¿Es Le Sillon socialista? Marc Sangnier es un cristiano que no puede admitir que la solución del problema social sea meramente económica. Se trata de un problema esencialmente moral y religioso. Por eso su objetivo es situar el catolicismo al servicio de la democracia.

La lucha por la mejora de las condiciones de la clase obrera no tiene como meta gozar, sino establecer la justicia. Por eso no son suficientes las reformas, hace falta que las inspiren principios éticos y que estos penetren en las conciencias. En la medida en que el socialismo es una doctrina del interés, se despreocupa de la educación moral del individuo, pero solo esta puede librar a la sociedad de su destrucción, víctima de una legalidad tiránica y de la acción represiva de una burocracia.

98 "... je ne puis me faire, auprès du Souverain Pontifice l'avocat d'un mouvement que ses prometeurs eux-mêmes n'ont pas encore bien défini et qui n'offre pas au catholiques les garanties necéssaires. Mais, si je n'ose accepter de le défendre, je demeure plein d'estime pour la jeuneusse dont il a su conquérir l'enthousiasme et qui, par ses talents et par ses vertus, se montre digne de servir dans une organisation moins contestée la cause de l'Église et celle de la France". Respuesta del cardenal Paulin Andrieu, arzobispo de Bordeaux, a Mgr. Eudoxe-Irenée Mignot, arzobispo de Albi, 31 mars 1910: Lettres sur le "sillon", texto impreso sin fecha. Un ejemplar, Ibídem: 18/2 56.

${ }^{99}$ Gaucherand, Fréderic. 1910: 6, 19 y 21.

10043472 Merry del Val-Pierre Couillié, arzobispo de Lyon, 12 de abril de 1910, ASV Segr.Stato 12 (1910) 14 114, copia Ibídem: 17 159. La carta era confidencial, pero podría dar noticia de ella a los obispos, al pedirles que guardaran silencio. La carta, cuya copia envió Couillié a los otros obispos, fue publicada por el azobispo de Albi. Mignot-Pie X, 22 avril 1910, Ibídem: 125-126. La respuestas de los obispos, Ibídem: 17 100-147 y 160-176

${ }^{101}$ Vid. este comentario en Le Sillon, 10 mai 1905. 
El socialismo todo lo funda en el Estado. No cree en la iniciativa privada. Sustituye al pequeño patrono burgués por un patrono omnipotente. Los "sillonnistes" no quieren ser funcionarizados ni acuartelados, sino fundar la democracia en la iniciativa y en la libertad. Le Sillon, en cambio, no cree en la eficacia de la lucha de clases, ni en otros medios violentos.

Marc Sangnier no quiere introducir de contrabando el cristianismo en el socialismo. Está de acuerdo con Jules Guesde en la concepción del capitalismo como una fase, que será superada, como lo fue el feudalismo. No era un sistema intangible. En ese rechazo al capitalismo se sentía al lado de Albert de Mun y de La Tour du Pin.

Había un punto, que no compartía en la crítica de los socialistas, el vincular catolicismo y capitalismo. Aunque se socialicen la propiedad y las fuerzas productivas, deberá permanecer ese tipo propiedad privada que garantiza la libertad del individuo y de la familia. Siendo de derecho natural, la propiedad privada, no es la única forma de propiedad. Por eso cabe la propiedad social para las grandes empresas y que las que producen bienes de interés general sean propiedad del Estado.

La originalidad de Le Sillon en el plano económico es la importancia que otorga a la propiedad social. La cooperación disolverá la gran propiedad capitalista. Para que se produzca la emancipación económica del trabajador es necesario que desaparezca la propiedad empresarial. Aceptando esa propiedad corporativa, no podría admitirse el proyecto de suprimir a los empresarios, aunque eso se plantee como una sustitución, cuando su función haya dejado de ser necesaria.

La creación de cooperativas de producción es un objetivo recomendable. Es un acierto el ataque al colectivismo, al materialismo económico y al capitalismo, cuyo funcionamiento concreto, se examina no como un modelo ideal, sino como una realidad opresora y abusiva. Hay en este punto una diferencia entre católicos sociales y socialistas. Los primeros creen en la reforma del edificio del capitalismo liberal. Los segundos buscan destruirlo. Marx sólo reconoce como fuente de riqueza el trabajo del obrero, pero los pensadores católicos afirman que hay otros dos factores: el capital y la cooperación empresarios-obreros Esta tendencia a reemplazar al empresario aproxima a Marc Sangnier más a los socialistas que a los católicos sociales. El respeto a la propiedad es meramente platónico si no incluye el respeto a la actividad empresarial.

Sangnier nivela el sistema de salarios con la esclavitud. La Iglesia la aceptó como un hecho, pero le negó su sanción. Su proyecto, una democracia económica, no despoja al patrono, pero lo destrona.

En política, mantiene la autoridad, no aceptando ese principio de la soberanía popular, condenado por la Iglesia. La sociedad está integrada por desiguales. ${ }^{102} \mathrm{La}$ democracia necesita autoridad. Hay un sueño en todo el proyecto de Marc Sangnier. En ese horizonte de una democracia cada día mayor, olvida la existencia del mal, del pecado original. Por eso habría que rebajar las exigencias y trabajar en el marco de la sociedad, tal cual es, por un poco más de justicia.

Le Sillon no es socialista, porque admite un pequeña propiedad privada y rechaza el colectivismo y, en cierto modo, la lucha de clases. Pero, pidiendo una transformación de la organización y del concepto de autoridad social, armando a los

102 Pío X motu proprio del 18 de diciembre de 1903, Pii X Pontiificis Maximi Acta, Roma 1905, 117-125. 
sindicatos contra los empresarios, favorece un socialismo mitigado. "Plusiers évêques ont vu là un danger". ${ }^{103}$

Pierre Louis Péchenard, obispo de Soissons, consideraba necesario, para comprender la situación de Le Sillon, estudiara su recorrido desde $1893 .{ }^{104}$ Nació en el colegio de Saint Stanislas, de París. Era un movimiento de jóvenes, que buscaban su formación cristiana y el apostolado, especialmente en los ambientes populares. Estaban dispuestos a dejarse degollar por Jesucristo. Formado por jóvenes luchadores, tuvo una aceptación inmediata por parte del clero y de los católicos. Miles jóvenes estaban bajo su esfera de influencia. Esta fase dura hasta 1899. En esa fecha se transforma en partido político.

Hasta 1905 se produce una transformación que les lleva a la política tras haber entrado en la acción social. El puente para pasar fue la palabra democracia. ${ }^{105}$ Eso supuso una secularización de su dimensión religiosa. La fe se reducía a ser levadura al servicio del ideal político. ${ }^{106}$ Desde 1905 cada "sillonniste" es católico, individualmente, pero el catolicismo no se incluye en la acción común. Ese año rompe con la Association Catholique de la Jeuneusse Française. Es un partido republicano. ${ }^{107}$ En todo este proceso, permanece el influjo decisivo de Marc Sangnier, un jefe que carecía de la preparación adecuada para dirigir este movimiento. Algunos destacaban ese hiperliderazgo como una forma de autoritarismo, defendido y practicado por quienes luchaban por la democracia política, económica y social.

¿Qué querían los "sillonnistes"? Que la República burguesa llegara a ser de los proletarios. Estos deberían ser educados para la democracia por los sindicatos. Buscaban, además, del bienestar material de la clase más despojada, su crecimiento moral e intelectual. Deseaban que tomasen conciencia de su responsabilidad civil y social. ${ }^{108}$

Su estrategia incluía medidas legislativas, organización social, sindicalismo, y educación democrática, que desplace el egoísmo ateo por la entrega al interés general. Ese tono utópico tiene mucha aceptación, pero supone también el riesgo de que Marc Sangnier sea un irresponsable que aboga por una revolución, cuyo norte sea una quimera. Esa vaguedad le hace hablar de mejorar lo que existe, pero sin concretar qué ni cómo.

Esta evolución, pública ya en 1908, despierta la inquietud entre muchos católicos. Los obispos retiran su apoyo a Le Sillon y lo critican. Desde entonces, tratan sus dirigentes de reformular su postura. Acentúan su afirmación de que son católicos y de que obedecen al papa. Pero esa confesión no destruye la sospecha que existe sobre ellos. Primero reducen toda la autoridad a la del Papa. Mientras

${ }^{103}$ M. Charles, «"Sillon" et socialisme», La Croix, 15 avril 1910, 3-4.

104 Se trata de la repuesta a la consulta sobre la oportunidad o no de condenar a Le Sillon, Soissons 24 avril 1910, ASV Segr.Stato 12 (1910) 17 218-249.

105 Su revista va cambiando de subtítulos. Hasta 1903: "Le Sillon, revue d'action sociale catholique". Desde ese año hasta 1905: "Le Sillon, revue catholique d'action sociale". Y a partir de ese año, "Le Sillon, revue d'action démocratique".

106 "Le Sillon, c'est la religion catholique se refaissant, conquerante du pays de France en acceptan loyalement le terrain politique et social qui existe", Le Sillon, 25 mars 1904.

107 Le Sillon no es un movimiento confesional católico, sino laico, cuyo objetivo es social y político. Carta de Marc Sangnier a Le Matin y a La Croix, agosto de 1906. De ese modo el movimiento se sentía exento de la sumisión a los obispos que exigía Pío X a las obras católicas.

${ }^{108}$ Para el obispo Péchenard era una actitud idealista, que ignoraba la existencia del pecado original. 
este no habla, desobedecen a los obispos, a quienes no reconocen el derecho a preguntarles por el movimiento.

Las acusaciones sobre su doctrina van coincidiendo en estos puntos. No aceptan que la Iglesia tiene autoridad en el terreno social, a pesar de que hay en él una dimensión moral. No admiten que quienes hacen propaganda religiosa deban estar bajo la obediencia de la jerarquía. Tienden a concebir la estructura de la Iglesia en claves democráticas. Solidarizan el catolicismo con su "República Democrática". Por eso dicen que son republicanos y demócratas porque son católicos. Desean que la República Democrática sea cristiana, pero, en la lucha por llegar a ella, subordinan la religión a la política.

Afirman que la educación popular se inspira en los principios evangélicos, pero desconocen que es la Iglesia la que los conserva e interpreta con su autoridad. Se reconoce a esta un derecho de control sobre lo que se hace, pero no el de intervenir "preventivamente". ${ }^{109}$ Sobre el Papa, su postura queda reflejada así: no postrarse ante él como un ídolo porque es un padre, no un señor, ni un déspota. ${ }^{110}$

En su lenguaje Le Sillon refleja su proximidad con el protestantismo y el iluminismo. Hablan de una vida, de un movimiento que evoluciona y se rectifica a sí mismo. Eso les da una presunción de inerrancia.

Tras optar por la política, crea jóvenes exaltados. Los hipnotiza o seduce, de modo que pierden capacidad para criticar a sus jefes y para reflexionar sobre sus ideas. Los siguen con una fe entusiasta. Hay un entusiasmo sentimental, que les permite conciliar actitudes contradictorias. Se gloriaban de su terquedad en las dificultades y en el debate. "Nous sortirons de la lutte plus entêtés". ${ }^{111}$

Los ataques y las censuras reforzaron su unidad. Sembraban la discordia entre los laicos, los sacerdotes y hasta entre los obispos. Criticaban ahora, abiertamente, a la Association Catholique de la Jeuneusse Française. La estaban destruyendo. Se habían acostumbrado a resistir a los obispos, a discutir sus decisiones y a limitar su autoridad. Las conversiones logradas por Le Sillon eran numerosas, pero habría que explicarlas una a una. A cambio, muchos jóvenes se habían desequilibrado.

Un laico, Marc Sangnier, pretendía dirigir la acción apostólica y social del clero e imponerle una forma de hacer política y proselitismo político. Había lanzado a los sacerdotes jóvenes a un terreno, ajeno a su vocación. ${ }^{112}$ Tenían ideas temerarias y formaban grupo aparte. No se fiaban de la autoridad. Eran indisciplinados. Muchos de los lectores de sus escritos eran seminaristas y curas jóvenes.

La relación de los "sillonnistes" con los obispos depende de cómo estos tratan a su movimiento. Hacen igual con el Papa. Marc Sangnier se cuidó de ocultar las

109 Esta posición había sido condenada formalmente por Pío X en su carta al cardenal Domenico Svampa, arzobispo de Bolonia el 1 de marzo de 1905, Pii X Pontificis Maximi Acta, Roma 1907, 53-55.

110 "Rien de moins chrétien que cette étrange conception, nous ne sommes pas des esclaves, mais des enfants nous sommes les fils de la loi nouvelle et nous avons étes engedrées, non de la servitude, máis de la liberté.

Le Pape est pour nous un père, non un maître. II est si peu notre maître que le langage toouchant le catholicisme véritable se plaît à en saluer du nom sublime de "serviteurs des serçviteurs de Dieu". Le Pape, texto recogido en Barbier Emmanuel. 1907: 121-123.

${ }^{111}$ Marc Sangnier, “Pour quoi je suis candidat”, L'Éveil Démocratique 28 février 1909.

112 La forma en que Marc sangnier dirige su movimiento y a los sacerdotes que en él trabajan es "absolue, aveugle, fascinante...supplante la direction du Pape". 
observaciones que Pío X le hizo en 1907. Repetían que los obispos que los condenaban lo hacían por ser republicanos. Eso era una calumnia. No actuaban de buena fe. No parecían conocer la misión de los obispos en la Iglesia y el deber de obedecerles. Para ser justos habría que decir que nunca se había dado un caso en que un sacerdote no se sometiera a su obispo.

Decían que la Iglesia carece de un modelo de organizar la sociedad. Ni el obispo ni el sacerdote reciben, por su ordenación, cualificación para defender uno u otro. Aceptaban la autoridad moral de la iglesia sobre el individuo y la sociedad para controlar lo que se hace, no para ordenar lo que deba hacerse. Para mantener esa posición, después que Pío X dijera que una obra es católica si actuaba bajo la autoridad del obispo, Le Sillon se definió como una obra puramente política.

Sus contactos con los partidos anticatólicos o acatólicos, con los librepensadores protestantes y socialistas eran evidentes. Lo juzgaban necesario para llegar cuanto antes a la República Democrática. Esta colaboración es una ilusión y un peligro.

"Qu'on ne s'y trompe pas; il s'agit dans la catholicisme d'aujourd'hui d'un choc formidable des deux mentalités, de deux catholicismes".

Estas palabras de Marc Sangnier, escritas el 3 de marzo de 1907 probaban que tenía clara su meta y sabía el significado de su opción. Había que desbordar el marco confesional para hacer política y crear la unidad en torno a un centro moral que se proyectaría políticamente en "una república democrática asentada en la justicia y la fraternidad". Su contrapunto era rechazo de toda vinculación con la Association Catholique de la Jeuneusse Française. Se declaraban también contrarios a la Action Libérale Populaire y en oposición a toda fuerza católica. Se engañaban creyendo que se inspiraban en el amor y eran obedientes a la Iglesia.

¿Habría que condenar Le Sillon? Para responder, debe considerarse la fuerza real que significaba este movimiento. Siendo laico y político, urgía conseguir que el clero no se solidarizara con él. Sus errores no se situaban en el plano doctrinal, pues son más tendencias y estilo que proposiciones precisas. Por eso estimaba Péchenard excesiva una condena pública. Bastaba una advertencia grave y prohibir al clero participar en sus actividades. Podrían atender a los "sillonnistes" como fieles, individualmente, sin formar parte del movimiento.

¿Cómo había planeado Marc Sagnier y los suyos la defensa de Le Sillon? Cuando el responsable de Le Sillon en Nancy supo que el obispo, Charles F. Turinaz, iba a condenar Le Sillon, prohibiendo a los sacerdotes dar la absolución a los sillonnistes, avisó a Marc Sangnier. Inmediatamente, con el apoyo de M.-J. Rodel, de Burdeos, acudió al arzobispo de Albi, E. Mignot. ${ }^{113}$ No teniendo este autoridad sobre el obispo de Nancy y temiendo que su intervención en Roma

${ }^{113}$ Mignot y el arzobispo de París, Léon A. Amette, fueron alumnos de Hogan, un sulpiciano irlandés, que estuvo de profesor en el seminario de Saint Sulpice durante diez años, antes de ser destinado a Estados Unidos. Fue este maestro quien dio a Mignot fama de persona de ciencia en los ambientes de Inglaterra y de Estados Unidos. El seminario de Albi estaba "absolument infesté du modernisme". Datos 16 marzo y finales abril 1910, en ASV Fondo Benigni 6, 75921 y 75516 . La acción de Hogan perduraba en el Instituto de París. La incorporación de quienes estudiaban en este centro, como profesores; en los seminarios los estaba contagiando de modernismo, "France. Paris", 22 marzo 1910, Ibídem: 808174 
tuviera efectivos negativos, decidieron poner en marcha una encuesta a los obispos.

Rodel estuvo con el obispo de Frejus, Felix Guillibert, que viajó a Roma. No tuvo una buena acogida. Pero antes de marcharse consiguió que el Papa evitara la condena decretada por Turinaz. Conseguido esto, Mignot puso en marcha su iniciativa. Sólo se opuso el cardenal Paul Pierre Andrieu, arzobispo de Burdeos, como hemos visto.

Tras ese taceant omnes, ordenado por Roma, los responsables de Le Sillon trabajaban discretamente en Roma y en Francia, informando sobre el movimiento. Estaba en juego en esta gran partida, según sus adversarios, además de Marc Sangnier "tous les modernistes de la démocratie". ${ }^{114}$

En esos momentos Denis Cochin tras informar al arzobispo de París, Léon Amette, fue Roma, para tratar de invitar a la Santa Sede a una conciliación con Aristide Briand. L'abbé Lemire había sido elegido en Hazebrouck, departamento del Nord. Le apoyó el bloque radical y socialista. Uno de los que le ayudó económicamente fue el arzobispo de Albi. ${ }^{115}$ Aunque a finales de agosto podría decirse que el lemirismo perdía posiciones en el Flandes francés, pervivía su espíritu de rebelión, que le arrastraría hasta el socialismo. Esa supervivencia de las ideas de Lemire se explica por el carácter obstinado de los flamencos. El arzobispo François Delamaire se limitó a censurar, pero no tomó medidas. ${ }^{116}$

Parece que el cardenal Merry del Val encargó un informe a H.-L. Bougouin, obispo de Périgueux. Su primera afirmación es capital para comprender el universo de ideas y sentimientos en que surge Le Sillon. El $75 \%$ del clero procede de ambientes populares, donde dominaban las ideas democráticas. Las expresiones más comunes entre los curas son "entrega a todos", "abandono de los propios criterios por el interés general"... Su meta es ser buenos sacerdotes y conquistar cada día una independencia mayor de pensamiento y de vida, dejándose inspirar por ese ideal democrático-republicano.

Visto desde fuera, el arraigo de los sillonnistes entre el pueblo era escaso. Marc Sangnier fracasó dos veces en su intento de ser elegido diputado. En los ambientes populares existía incompatibilidad entre religión y socialismo. ${ }^{117}$ Le Sillon había enraizado en el clero. ${ }^{118}$

114 "France. Sillon", 6 mayo 1910, ASV Fondo Benigni 6761 23-24. Marc Sangnier había sio derrotado por un candidato monárquico en las legislativas, "France. Quelques diocèses", finales abril, Ibídem: 766230.

115 Una descalificación de esa gestión y de la orientación política de la Action Libérale Populaire, 9-10 y 14 mayo 1910, Ibídem: 762-765 25-28.

116 "Cambrai, Notes sur le lemirisme", fin d'août 1910, ASV Fondo Benigni 1223 339, repetido en 230345

117 En 1901 se comenzó a editar en Italia // Seme, un periódico que trataba de difundir el socialismo religioso entre los campesinos. Tenía difusión nacional. Era anticlerical, pero apelaba a la Biblia y a la tradición cristiana para establecer lazo de unión entre el cristianismo y el socialismo. Dominici, Silvia. 1995. La lotta senz'odio. Il socialismo evangelico del "Seme" (1901-1915), Milano: Franco Angeli.

${ }^{118}$ Es un texto extenso, manuscrito por el prelado, donde se hace el relato de la orientación del movimiento desde 1903 hasta el 20 de mayo de 1910. ASV Segr.Stato12 (1910) 17 179-189. 
"Le pontificat de Pie $X$ soumet l'Église à la plus redoutable des crises qu'elle ait eue depuis le XIII siècle. Le 2/3 du jeune clergé est perdu pour les idées conservatrices". ${ }^{119}$

Al tomar una decisión sobre Le Sillon, la Santa Sede deberá evitar cualquier expresión que se preste a equívocos. Importa esto a la vista de lo que había sucedido con el nombramiento de censores de libros, previsto en la Pascendi. Los sillonnistes tienen una especial habilidad para convertir en aprobación cualquier reproche. Quienes argumentan con la astucia de Marc Sangnier se equivocan al concluir que no deben tomarse medidas contra Le Sillon. Hay que tener presente la disposición de los sillonnistes y de su jefe para calcular los efectos de la medida, no para renunciar a ella.

No debian exagerarse las consideraciones hacia las personas, salvo con los laicos, pero no debería haber esa benevolencia con los obispos, superiores de seminario.

Todos los errores de Le Sillon derivan de su concepto de democracia: "l'organisation sociale qui tend à porter au maximum la conscience et la responsabilité civiques de chacun". Se deja en segundo plano la dimensión moral. Se descuida que sólo, si el cristianismo influye en la minoría, eso es posible.

Marc Sangnier afirma que habrá democracia cuando los ciudadanos participen efectivamente en la elaboración de las leyes, cuando estén estas bajo su tutela y sean la expresión viva del pensamiento y de la conciencia, nacionales. El cristianismo para alcanzar socialmente su fin necesita de la democracia, ha de iniciarla y fomentarla.

Creer eso posible es excesivo. En ningún lugar de la Escritura se anuncia que esa transformación llegará a realizarse. Basta mirar a la Iglesia donde ese modelo no se ha logrado. Si se llegara a lo que Marc Sangnier propone desaparecería la autoridad, porque el pueblo se gobernaría a sí mismo. Solo quedaría la autoridad de Dios. La autoridad civil, la apariencia de ella, se limitará entonces a interpretar la conciencia nacional, que llegará a su plenitud por la acción conjunta del cristianismo y por el impulso de la democracia.

Desde el punto de vista económico eso supone la desaparición de los patronos, cuya autoridad es menos necesaria que la autoridad civil.

Fundamento de toda esa concepción es el individualismo. La referencia al cristianismo excluye la subordinación al magisterio de la Iglesia. Esta es la razón para golpear decisivamente a Le Sillon, condenando su idea de la democracia. La Iglesia no puede condenar esta, pero sí los aspectos que conducen a varios errores. El primer de ellos la tendencia a la autonomía que muestra Le Sillon en la formación religiosa y moral. Marc Sangnier no someterá su causa a la Santa Sede.

La praxis de Le Sillon, su pretensión de injerirse en la vida de la Iglesia favorece la penetración en los seminarios. Usa para ese fin un minimismo doctrinal en exégesis, dogma e historia de la Iglesia. "Le modernisme n'a pas de véhicule plus assuré que Le Sillon". Debe prohibirse a los sacerdotes participar en sus actividades. ${ }^{120}$

${ }^{119}$ Carta de Paul Sabatier a Ernesto Filippini, pastor valdese, Asissi 18 abril 1910, Bedeschi, Lorenzo 1987-1988. "L'affaire L. M. Fantoni e la fine de l'amicizia Luigi Piastrelli-P. Sabatier". Fonti e Documenti 16-17: 489-491.

${ }^{120} \mathrm{El}$ autor de este informe cita a Naudet, Dabry. Desgranges, Lestang. "Notes sur Le Sillon par un Supérieur de Grand Seminaire", sin fecha, pero antes del 23 de septiembre de 1910. ASV 
El obispo H.-L. Bougouin envió el 22 de julio su respuesta al informe pedido por el Cardenal Merry del Val. No quería dejar dudas sobre su posición. El asunto Le Sillon le recordaba las palabras de Dom Gueranger, restaurador y abad de Solesmes, y del cardenal Pie, señalando, como más peligrosos que los verdaderos herejes, aquellos que se dedican a mutilar la verdad y conseguir que se acepte así.

Reitera este escrito las acusaciones del grupo de obispos favorables a una condena. Los sillonnistes estaban contaminados por una doctrina errónea, que se difundía de forma "si insinuante et si perfide". Esta era la clave. No se trataba de una doctrina, sino de un espíritu. Marc Sangnier decía que Le Sillon no era un cuerpo, sino un alma, un espíritu, no una organización. Por eso no era fácil presentar proposiciones y afirmaciones heréticas. Tenía su propia tradición.

La primera acusación del obispo Bougouin era que no obedecen a la Iglesia. Dejó de ser confesional para presentarse como autónomo, independiente y laico. Actuaba en los ambientes católicos, buscando despojar al catolicismo de adherencias que lo desfiguraban. Querían vivir como católicos. Por eso Le Sillon pertenecía a la Iglesia. No reconocerlo así era una desviación, que negaba su propia historia y el motivo de su aceptación a partir de 1893.

En su acción social y en la labor de educación democrática, se habían apartado hacia tiempo de las orientaciones de León XIII. ${ }^{121}$ Sistemáticamente elude la obediencia al Papa. No observaba las normas sobre las relaciones entre católicos en la acción social y política.

"Il resulte, du reste, du libéralisme pratique, qui parait être "l'esprit" du Sillon et constituer "l'âme commune" des sillonnistes".

En cuanto a la doctrina, más que a sus escritos y discursos, había que recurrir a sus "compañías". ${ }^{123}$ Citando a Pío IX, el obispo acusaba a los católicos que confraternizaban con quienes habían sido condenados por la Iglesia, de secundar sus planes sin que se notara. "Le Grand Sillon" conduce a relaciones frecuentes y a colaboraciones cada vez más amplias con protestantes, librepensadores y socialistas. Por esa vía, habían llegado a subordinar el cristianismo a su proyecto político. El cristianismo es útil a la democracia, le es indispensable. La religión era levadura de ese ideal político. Expresaban su experiencia de fe en términos similares a los del modernismo.

Para tomar una decisión, debía tenerse en cuenta la realidad de Le Sillon y la personalidad de su jefe. Este se creía revestido de una misión divina. Aconsejaba el obispo prohibir a los clérigos ser "sillonnistes", pues su pertenencia los secularizaba. Urgía atender especialmente a los seminarios, pues por la edad, sus alumnos eran más sensibles a la mentalidad sillonniste. Era preciso actuar luego con la vista puesta en recuperar todo lo positivo que hay entre los "sillonnistes",

\footnotetext{
Fondo Benigni 81083 414-417.

${ }^{121}$ Como otros informantes, el obispo de Périgueux ve una contradicción entre la afirmación católica que hacen los "sillonnistes" y la definición de su movimiento como aconfensional.

${ }_{122}$ Sobre estas expresiones, usadas para mostrar la identidad de Le Sillon, se observa que son retóricas a la vista de las divisiones que había tenido. En 1907 Jean Desgranges denunciaba que se había convertido en "une monarchie absolue, soumise à l'autorité exclusive de Mar Sangnier", Barbier, Emmanuel. 1907: 195-242.

${ }^{123}$ El obispo cita a Charbonnel, un apóstata, Laberthonnière, Naudet, Dabry, Lemire, Klein, Fogazzaro, Murri...
} 
pidiendo mayor precisión en sus escritos y pronunciamientos públicos y apartar a Marc Sangnier y paralizar la actividad de los círculos sillonnistes. ${ }^{124}$

\section{NOTRE CHARGE APOSTOLIQUE}

El 30 de mayo de 1910, tras las elecciones legislativas, la Action Libérale Populaire envió un documento a todos los periódicos, analizando el triunfo en París. Un sillonniste recibió 10000 sufragios en el distrito de Péronne.

Las derrotas eran causadas por la desunión. La unidad proporciona las victorias. Las elecciones de 1910 habían sido una lección. Marcaban el final de un sistema y el comienzo de una era nueva. El país sacudía sus cadenas e iniciaba su liberación. El Bloque había sido derrotado y había sufrido una sacudida en su interior.

Había terminado la política sectaria de los últimos doce años. La sociedad francesa había gustado ya la justicia y la libertad. No retrocedería. La representación proporcional había obtenido 5 millones de votos, la reforma administrativa casi otro tanto. La libertad de enseñanza contaba con 298 diputados electos. Condenado el escrutinio de distrito, gran instrumento de fraude, condenado el régimen administrativo, que permitía a los prefectos actuar como tiranos y convertir a sus delegados en espías, sin los favores corruptores, sin sus secretos para rebajar la moralidad, y había sido además condenado el monopolio de la enseñanza, la cúpula del edificio sectario. Ese era el balance

Estos objetivos estaban en el programa de la Action Libérale Populaire. Las alianzas hechas nada tenían que ver con la "politique du pire". Se habían limitado a sostener a los candidatos que compartían su programa o estaban muy cerca de él. A nadie habían sacrificado en aquellos distritos donde sabían que no obtendrían mayoría. No habían tomado partido por quienes no compartían sus ideas. Se habían limitado a declarar que estaban por la proporcional, la reforma administrativa y la libertad de enseñanza.

A quienes los acusaban de haber dirigido sus votos a los enemigos de la propiedad, habría que recordarles las expropiaciones de los bienes de las Congregaciones, realizadas por el gobierno sostenido por el Bloque. Era la hora de organizarse para dar una meta al movimiento económico y social aparecido en Francia. ${ }^{125}$

Esos días los "sillonnistes" temían una condenación por parte de Roma. Esperaban que fuera una carta al cardenal Paul Pierre Andrieu, asumiendo lo dicho por el arzobispo de Burdeos. Había que visitarlo y ver el modo de evitar una censura pública. Si eso no se conseguía, la salida sería crear una sección juvenil, con consiliarios nombrados por los obispos, que tuvieran una autoridad puramente nominal. Para los adultos se crearía un partido republicano y demócrata, que quedara fuera del control de la autoridad episcopal. Los obispos no podrían reclamar el derecho a intervenir, pues no lo hace ni en la Action Française ni en las

124 Texto íntegro y carta anunciando su envío, ASV Segr.Stato 12 (1910) 17 273-297.

125 Los enemigos de Piou lo tachaban de ir junto a los sillonnistes, de ser ambiguo, al hablar de liberación sin adjetivarla de católica, de movimiento económico y social, dejando a un lado el movimiento católico, de ser ambiguo en el concepto de libertad de enseñanza, de cometer la ingenuidad de colocarse al lado de Briand y de haber dejado todo su programa reducido a votar por la proporcional. Copia mecanografiada del documento de Action Libérale Populaire con comentarios de los católicos integrales, de la Correspondence de Rome y de L'Univers, ASV Fondo Benigni 35 4775 134-137. 
otras organizaciones donde hay católicos. Esta estrategia se remonta a 1906, cuando Marc Sangnier fue condenado por el obispo de Quimper. ${ }^{126}$

Los demócratas y los sillonnistes trabajaban para hacer creer que el prestigio del Papa estaba en declive. No era así. Lo probaban las aclamaciones de quienes estuvieron en la manifestación de Juana de Arco, que hubo en Paris. Miles de hombres, especialmente de jóvenes, vitoreaban a Pío X. Todo ese clima lo favorecía la Action Française.

Este ambiente podría ir a más pero lo detenía la actitud de algunos que desconcertaban a estos católicos intransigentes. Se apuntaba a estos hechos positivos: el rechazo de la separación, la beatificación de Juana de Arco y la condena de Le Sillon. Un punto negativo era los nombramientos episcopales. El Papa quizás no conocía a las personas. Los nuevos obispos en lugar de servirlo, no cooperaban en su proyecto de despertar a los católicos. ${ }^{127}$

El obispo de Niza, Henri Louis Chapon estuvo hablando con Sangnier durante tres horas ante la inminencia de la condena de Le Sillon. Tuvo la impresión de que no había posibilidad de seguir con él, porque se negaba a entender la situación y se rebelaba contra Roma. El obispo de Versalles, Charles Gibier, había prohibido a los seminaristas ser miembros de Le Sillon. ${ }^{128}$ Los seminaristas ordenados en la última promoción se presentaron al superior del seminario mayor para declarar que todos eran sillonnistes. Juzgaban su deber hacer esta declaración para manifestar la firmeza de sus convicciones. ${ }^{129}$

En ese escenario, el 25 de agosto, se publicó al encíclica. Pío X, al elegir ese nombre, manifestó un deseo y anunció un proyecto.

"Confiant dans les suffrages de saints Pontifes, qu'ont honoré le nom Pie par les vertus et qui on défendu l'Église avec force et avec douceur, je veux être appelé Pie X"

Notre Charge Apostolique ${ }^{130}$ condenó Le Sillon por su pretensión de autonomía frente a la autoridad eclesiástica, lo acusó de haberse contagiado de espíritu revolucionario. Por eso eran erróneas sus doctrinas, su espíritu, peligroso y su educación de los jóvenes, funesta.

En tiempos de anarquía social e intelectual, recordaba el Papa, cuando cada uno se convierte en doctor y legislador, hay que proclamar que la sociedad no

${ }^{126}$ Dos datos a añadir a este informe: la tendencia de la Action Catholique de la Jeneusse Françaisehacia la izquierda siguiendo el ejemplo de Albert de Mun y sus intentos de unión con Le Sillon, rechazados por Marc Sangnier. "France. Le Sillon". documento firmado por Benigni como Jérôme, 10 junio 1910, ibídem: 81100 521-525.

127 "Pie X et les intrangeants", 15 juin 1911, Ibídem: 346823.

128 "France. Nouvelles religieurses", 19 junio 1910, Ibídem: 6841251.

129 "Cambrai, fin d'août 1910, Ibídem: 1223 339. El intercambio de ideas entre el arzobispo Delamaire y Marc Sangnier, primero a través de Tiberghien y, luego, de Flip, rector del seminario mayor, víspera de las ordenaciones, Lille septiembre 1910, Ibídem: 227342.

${ }^{130}$ Resumen oficial del documento y dos ejemplares con el texto original en frances, ASV Segr.Stato 12 (1910) 15 7-9. Hay un borrador que se inicia con "Le moment est venu", texto mecanografiado, Ibídem: 18/2 9-52. El texto no se encuentra en la Web de la Santa Sede. Una traducción española con error en la fecha, 23 de septiembre, www.statveritas.com.ar/ 
puede construirse nada más que como Dios la ha fundado. Por eso es imposible construirla si la Iglesia no pone los cimientos y dirige los trabajos. ${ }^{131}$

Pese a las rectificaciones de Marc Sangnier, el contenido continuaba teniendo valor, pues se refería a la doctrina y al espíritu de Le Sillon, que no habían variado. El documento no iba dirigido a las personas. En él Pío $X$ reconocía la fe y la fidelidad a las normas católicas observada en el movimiento. ${ }^{132}$

“...porque Nos amamos a la valiente juventud alistada bajo la bandera de "Le Sillon", y la creemos por muchos conceptos digna de elogio y admiración. Amamos a sus jefes, en quienes, Nos complacemos en reconocer espíritus elevados, superiores a las pasiones vulgares y animados del más noble entusiasmo por el bien, Vosotros los habéis visto, Venerables Hermanos, penetrados de su afecto vivísimo de fraternidad humana, ir al encuentro de los que trabajan y padecen, para sacarlos de la miseria y sostenidos en su sacrificio por el amor a Jesucristo y por la práctica ejemplar de la Religión". (n. 2)

"Sus fundadores, jóvenes, entusiastas y llenos de confianza en sí mismos, no estaban bastante pertrechados de ciencia histórica, de sana filosofía y de teología sólida, ni para afrontar sin peligro los difíciles problemas sociales y que los arrastraba a su actitud y su corazón, ni para precaverse, en el terreno de la doctrina y de la obediencia, contra las infiltraciones liberales y protestantes. (n. 4)

No faltaron consejos, a los consejos sucedieron avisos, "pero hemos tenido el sentimiento de ver que avisos y reprensiones se deslizaban sobre sus almas escurridizas sin producir resultado". Intervenía el Papa porque Le Sillon "siembra la discordia" entre los católicos que intervienen en la sociedad y en el interior de la Iglesia (n. 5)

Seguía el Papa las huellas de León XIII al describir el significado y la orientación de una acción social católica. ${ }^{133}$ La quería "dégagée de toute utopie et vigoureusement dirigée par des prêtres compétents sous l'autorité des évêques". EI motivo es que la ciudad cristiana no podría edificarse sino bajo la autoridad de la Iglesia.

No rechazaba la democracia como forma política, pues la Iglesia había dejado a los pueblos la libertad de elegir sus instituciones políticas. Recordaba sin embargo que la democracia no tenía como sistema una posición privilegiada para conseguir que reinara la justicia y el bienestar del pueblo.

¿En qué radicaba el error de Le Sillon? Primero, en su deseo de escapar a la dirección de los obispos. Eso era un ataque grave a la disciplina católica.

131 Durand, Jean-Dominique. 2003. "Pio X e la Francia": Pio $X$ e il suo tempo, a cura di Gianni La Bella: 681-689, cita 683 y 687 . Bologna: II Mulino.

${ }^{132}$ Pío X declaraba al comienzo de su encíclica su amor a "la vaillante jeuneusse enrôlée sous le drapeau du Sillon".

133 La Notre Charge ponía el origen de Le Sillon en la Rerum Novarum. Los "sillonnistes" elevaron ante la clase obrera la bandera de Jesucristo. Hablaron de Dios ante los que lo desconocían y los que lo combatían. Testimoniaron su fe en ambientes hostiles. Fueron los tiempos felices del movimiento. Ahora se había desviado del buen camino. Olvidaba su origen. 
Había querido conciliar el pensamiento del papa con el de los filósofos del siglo XVIII, con la revolución y con el liberalismo. ${ }^{134}$ De ese modo desfigura la dignidad humana, la libertad y la justicia, pues

"...il tend à l'émancipation politique, economique et intellectuelle du peuple, à l'abolition des inégalités sociales, au nivellemet des classes, à la suppression de toute autorité; c'est à dire, (quelque nuance qu'il y mette), il veut renverser les bases séculaires, naturelles de la societé pour mettre à leur place l'autonomie de chacun, l'égalité de tous, la fraternité universelle dans l'amour des intérêts communs'". ${ }^{135}$

No hay un orden exclusivamente temporal, pues todo lo humano está sujeto a la moral y por ende a la autoridad eclesiástica (n. 6). Toda obra social es moral y religiosa... afirmar lo contrario es un error (n. 7). El católico no debe sustraerse a la disciplina eclesiástica (n. 8). La doctrina católica y papal sostiene la diversidad de clases (n 9).

Labor encomiable de los "sillonnistes" estaba viciada de exageraciones nocivas. Sus esfuerzos por mejorar la condición de los trabajadores se pervierte porque "su sueño consiste en cambiar sus cimientos naturales y tradicionales y en prometer una ciudad futura, edificada sobre otros principios, que se atreven a declarar más fecundos, más beneficiosos que aquellos sobre los que descansa la actual sociedad cristiana (n. 10).

Existe la "ciudad" católica. Solo se trata de establecerla y restaurarla sin cesar sobre sus fundamentos naturales y divinos, contra los ataques, siempre renovados, de la utopía malsana, de la rebeldía y de la impiedad: Omnia instaurare in Christo" (n. 11).

Le Sillon tiene la noble preocupación de la dignidad humana. Pero esta dignidad la entiende a la manera de ciertos filósofos, de quienes la Iglesia dista mucho de poder alabar (nn. 12-13) pues pretenden una emancipación política, económica e intelectual desmedida. Libertad no es total emancipación política, económica e intelectual (n. 14) y el amor del interés público y del bien común, no es el principio supremo de la autoridad moral (n.15). Reclaman un desproporcionado y desordenado poder político, económico y moral para el individuo. Democracia no es la participación mayor posible en el orden político y económico, pues ni el súbdito es rey; ni el obrero, patrón.

"Ahora bien, estos tres elementos, político, económico y moral, están subordinados uno a otro, siendo el principal, según hemos dicho, el elemento moral. En efecto, imposible es que viva democracia política alguna si carece de raíces profundas en la democracia económica... pero, a la vez, ni una ni otra son posibles si no arraigan en tal estado de ánimo que la conciencia posea responsabilidades y fuerzas morales proporcionadas" (n.16).

134 Ese era el arranque de la encíclica. Sus planteamientos "ne relèvent pas du génie catholique et français"

135 "... nous avions raison de dire que le Sillon oppose doctrine à doctrine, qu'il bâtit sa cité sur une théorie contraire à la verité catholique et qu'il fausse les notions fondamentales qui règlent les rapports sociaux dans toute societé humaine". Sembraba, pues en la juventud, conceptos erróneos de la autoridad, de la libertad y de la obediencia. 
La educación democrática "sillonniste" se reduce exclusivamente a cultivar la conciencia y la responsabilidad cívicas (n. 17). En resumen, la teoría "sillonista" falsea la doctrina católica sobre ella. (n. 18).

Estas son las rectificaciones de Pío X. La autoridad pública procede de Dios, no del pueblo ni puede ser revocada por el pueblo (n. 19) la autoridad y la obediencia son necesarias y no coartan la libertad (n. 20). La desigualdad no es injusticia ni la democracia es el único régimen justo ni goza de especial privilegio ( $\mathrm{n}$. 21). Es falso y débil fundamento de la fraternidad el que se pone en interés común o en la simple humanidad. La caridad cristiana y Jesucristo mismo son la verdadera base de la fraternidad humana (n. 22).

El Papa rechazaba ese sueño, lleno de errores y de ilusiones peligrosas, restablecía la verdad sobre la autoridad en la sociedad, recordaba que la dignidad humana no es incompatible con la sumisión, ni la libertad con la autoridad. Es falso y peligroso decir que toda desigualdad es injusta. La fraternidad humana es una realidad frágil. Sólo la caridad católica, fundada en el amor de Jesucristo y con sumisión a la Iglesia, puede unir de verdad los espíritus, los corazones y las voluntades. Eran estas ideas la fuente de la indisciplina que se les imputaba y de su desprecio al pasado. $Y$ todo esto no era una doctrina, sino un estilo de vida. Por eso el daño que producían en los jóvenes era mayor. ${ }^{136}$

El origen de todas estas falsas nociones sociales es la equivocada idea de la dignidad humana (n. 23). El Papa critica algunas prácticas de Le Sillon: la camaradería absoluta entre ellos con la eliminación práctica de diferencias (n. 25) y el quebranto consiguiente del respeto y de la obediencia en esa falsa sociedad son un peligro (n. 26).

En su praxis, Le Sillon subordinaba la religión a una opción política, afirmando que la democracia era el sistema que más favorecía a la Iglesia y mejor respondía a las exigencias del Evangelio. La subordinaba a la democracia y eso "lui permets de rester souvent inactif dans le conflict contemporain entre l'Église et la politique sectaire". Ya no proclamaban: La democracia será católica o no será", sino "La democracia no será anticatólica". Desde esta perspectiva convocaban a todos a trabajar por la ciudad futura, asegurando que la Iglesia no se aprovecharía de sus afanes. Le Sillon había dejado ya de ser formalmente católico. Se confundía con otros grupos. No trabajaba por la Iglesia, sino por la humanidad

Paso a paso, Pío X seguía ese descenso de Le Sillon, "ses vains efforts pour édifier le règne de la justice avec des élements si misérables dans une lamentable promiscuité". Esta orientación solo beneficiaba a los agitadores de masas, a los socialistas o, mejor aún, Le Sillon, separando a la Iglesia del Evangelio, enfeudando en su democratismo el evangelio mutilado, colaboraría en la fundación de una iglesia libre, universal, una religión de la humanidad como predican los modernos evangelistas.

En relación con la Iglesia, el Papa apunta que los sillonnistes se consideran los mejores católicos (n. 27). Su catolicismo es deficiente porque admite solo el régimen democrático (n. 28). Prescinden prácticamente de su Religión y, proclamándose católico, no defiende su catolicismo (n. 29). Le Grand Sillon postula la unión moral de todas las religiones y sectas, con total independencia de la

136 "Le souflle de la Révolution a passé par là et nous pouvons conclure que si les doctrines sociales du Sillon sont erronées, son esprit est dangereux et son éducation funeste". 
Religión (n. 30) La civilización supone la moral, y la moral, Religión... por eso en las realidades prácticas importa la convicción religiosa. (n. 31).

La "Junta democrática de Acción Social" propicia una imposible y peligrosa mezcolanza de religiones y convicciones (n. 32). No quieren que la acción social "sillonniste" beneficie a la Iglesia, en cambio ésta ha de ayudar a aquélla (n. 33). Es una quimérica empresa reemplazar con un vago idealismo y virtud cívica la obra inmortal de la Iglesia (n.34) El "Sillonismo" pretende ser una nueva religión (n. 35).

La conducta no católica de Le Sillon no satisface a la Iglesia. Su catolicismo terminó en apostasía organizada (n. 36). Su nuevo "Evangelio" tiene aspectos irrespetuosos y blasfemos (n. 37) Deforman el verdadero Evangelio y a Cristo, descartando su divinidad y acentuando sus virtudes sociales (n. 38).

EI Papa exhortaba a los obispos a que se preocupen de sus fieles más pobres y de la acción social. ${ }^{137}$ Que elijan sacerdotes, con formación filosófica, teológica e histórica. ${ }^{138} \mathrm{Al}$ consagrase a la acción social deberían tener presente que es un problema que viene de lejos. No deberían dejarse seducir por lenguajes llenos de promesas sonoras, pero irrealizables. La Iglesia, como hizo en el pasado, estaba dispuesta a cooperar con el Estado, sin aceptar alianzas que la comprometieran en actos que traicionaran la felicidad del pueblo. Le bastaba el concurso de los verdaderos artífices de la restauración social, "car les vrais amis du peuple ne sont ni révolutionnaires, ni novateurs, mais traditionnalistes".

“...la Iglesia que jamás ha traicionado la felicidad del pueblo con alianzas comprometedoras, no tiene que desligarse de lo pasado, antes le basta anudar, con el concurso de los verdaderos obreros de la restauración social, los organismos rotos por la revolución, y adaptarlos, con el mismo espíritu cristiano de que estuvieron animados, al nuevo medio creado por la evolución material de la sociedad contemporánea, "car les vrais amis du peuple ne sont ni révoluionnaires, ni novateurs, mais traditionnalistes" (n. 39).

EI Papa llamaba a los jefes de Le Sillon a ceder la dirección del movimiento a los obispos diocesanos.

"Nos medimos ciertamente la extensión del sacrificio que de ellos solicitamos, pero sabemos que son bastante generosos para realizarlo, y de antemano, en el nombre de Nuestro Señor Jesucristo, de quien somos representantes indignos, les damos por ello Nuestra bendición".

Pedía a los sillonnistes que se agruparan por diócesis "para trabajar bajo la dirección de los obispos respectivos, así en la regeneración cristiana y católica del

${ }^{137}$ Le Sillon, decía en su encíclica, quiso elevar la dignidad humana y mejorar la situación de humillación en que vivían los obreros, conseguir leyes laborales y relaciones entre patronos y asalariados justas, en una palabra, mayor justicia y caridad. Nadie podría reprocharles ni sus deseos ni sus esfuerzos en este terreno.

${ }^{138}$ El Papa interpretaba la acción de Jesús como una acción redentora que incluía reunir a todos "dans la justice et l'amour". Al llamar a los pecadores y descarriados no respetó sus errores. Al consolar a los cansados y abatidos no lo hizo prometiéndoles una igualdad quimérica. Si levantó a los humildes no fue para que su dignidad los hiciera independientes y rebeldes. Jamás anunció que el sufrimiento desaparecería de la sociedad. En este mundo, la dicha es posible. En el cielo, la felicidad completa. La cuestión social se resolverá cuando todos tengan una mayor conciencia de sus deberes y los cumplan. 
pueblo como en el mejoramiento de su suerte". Esta reestructuración buscaba quebrar la continuidad con la etapa anterior, con sus errores y sus líderes, dejando a cada uno "libre de conservar, por otra parte, sus preferencias políticas, depuradas de todo lo que en la materia no sea enteramente conforme con la doctrina de la Iglesia".

“...los sacerdotes y seminaristas, si bien los favorecerán y secundarán, se abstendrán, no obstante, de agregarse a ellos como miembros... porque conviene que la milicia sacerdotal se mantenga en una esfera superior a las asociaciones laicas, aun las más útiles y animadas del mejor espíritu". (n. 40)

Católico por encima de todo, Marc Sangnier quiso mostrar al Papa su obediencia filial. Era duro dejar los grupos de educación popular, en donde había gastado lo mejor de su vida, deseando hacer volver a la religión a los jóvenes que la habían abandonado. Se retiraba de los comités de dirección de la "Union pour l'Éducation Civique" y el " Comité Démocratique d'Action Sociale". ${ }^{139}$

Se marchaba con alegría. Dejar la vida pública significaba recobrar la paz después de haber sido combatido desde los puntos más contrapuestos. Con todo juzgaba su deber no encerrarse en una inacción "séduissante mais coupable". Sería acreditar en Francia esa idea falsa de que un católico no puede ser al mismo tiempo republicano y demócrata. Renunciar a esa convicción sería una forma de sumisión no católica y meramente exterior. ${ }^{140}$

Seguirían trabajando en el campo que el Papa les señalaba. Lo harían como ciudadanos sin olvidar que eran católicos, con artículos, discursos, dejando en claro que no defendían las opiniones condenadas por la Iglesia, especialmente las señaladas en la Carta del Papa. Citó una de ellas: su proyecto de crear una religión más universal que la Iglesia católica.

No quisieron deformar el evangelio ni el carácter sagrado de Jesucristo. Podrían haber dado lugar a estas interpretaciones, pero habían confesado su fe en Jesucristo y su amor a la Iglesia ante multitudes hostiles. No habían actuado por un humanitarismo sin consistencia, sino por el Dios hecho hombre y vivo en los tabernáculos de los templos católicos, que quiere servir de alimento a los más humildes de entre nosotros.

Atacados, despreciados y calumniados no sólo por los enemigos de la fe, sino por algunos católicos, solicitaban la bendición que el Papa les prometía en su carta.

Este acto de sumisión desatará la furia de sus enemigos, anticatólicos y sectarios, que les habían reprochado siempre su adhesión al Papa. Fuere cual fuere el futuro, incluso si tuvieran que sufrir la prueba de que el Papa dudara de su

139 Pidió el 6 de septiembre Marc Sangnier, en su carta circular a los "sillonnistes" una obediencia "humble, prompte et joyeuse". Quería, al presentar su dimisión, cumplir un último deber: "c'est de supplier mes amis d'agir en bons catholiques, sans aigreur et sans dépit", y que ofrecieran, sin reticencias ni segundas intenciones, su buena voluntad a sus respectivos obispos. Deberían hacer todos los sacrificios que Dios les pidiera "dans la aix et sans regret". Copia, ASV Segr.Stato 12 (1910) 17 259-260.

${ }^{140}$ Esta reacción de Marc Sangnier parecía la de un ultramontano. Sutton, Charles M. 1994. Maurras et les catholiques français. 1890-1914. Nationalisme et positivisme, Paris: Beauchesne. Original publicado en inglés en Cambridge 1982. 
lealtad, se considerarían felices sabiendo que habían sido dignos de sufrir por Cristo. ${ }^{141}$

Las pruebas por las que pasaban los "sillonnistes", soportadas con humor y sin quejarse, iban a permitirles continuar trabajando sin descanso,

"avec une prudence mieux avertie, une foi plus éclairée, un dévouement plus affermi pour l'Église que nous laverons d'injustes réproches et pour a France qui mérite une autre République que celle que les sectes antichrétiennes lui ont préparé mais où étouffe son âme généreuse". ${ }^{142}$

El cardenal Léon Adolphe Amette, arzobispo de París, subrayó el vigor y la claridad del Papa, denunciando los errores doctrinales y la conducta equivocada de los "sillonnistes". Puesta a prueba su fidelidad a la Iglesia, tan elogiada por el Papa, habían sabido hacer honor a ella. Marc Sangnier se había presentado ante su arzobispo "se déclarant prêt à tous les sacrifices pour donner pleine satisfaction aux désirs du Souverain Pontife". ${ }^{143}$

De todas partes llegaron noticias de la sumisión de los "sillonnistes". ${ }^{144} \mathrm{El}$ arzobispo de Albi dijo al Papa que esa respuesta a su carta acreditaba a los obispos que, como él, defendieron siempre la fidelidad de Marc Sangnier y de sus seguidores. ${ }^{145}$

Los que se consideraban fieles a la tradición secular de los grandes obispos y de los grandes reyes franceses se alegraban de que el Papa hubiese condenado "une erreur multiforme aussi fuyante que séductrice". ${ }^{146}$ Otros elevaron la autoridad del documento considerándolo un acto infalible, ${ }^{147}$ pero no lo era.

La supervivencia de Le Sillon podría quedar asegurada gracias a la red de intereses económicos que estaban creándose. Sus dos focos: La Démocratie y las Cooperativas. Había además una librería, donde se vendían todos los escritos de Marc Sangnier, sin que se hubieran introducido en ellos rectificaciones después de la condena pontificia.

${ }^{141}$ Marc Sangnier-Píe X, 30 août 1910. La carta se transmitió a través del cardenal Merry del Val, a quien también escribió el 1 de septiembre, ASV Segr.Stato 12 (1910) 15 2-4 y 25. Hay una cita implícita de Act. 5, 40-41.

142 Marc Sangnier, "Des Preuves", La Démocratie 18 (3 septembre 1910) 1.

143 Lettre de Monseigneur l'Archévêque de Paris a $\mathrm{mm}$. les curés de son diocèse relativement a la Lettre de N.T.S.P le Pape Pie $X$ sur le Sillon, 5 de septiembre de 1910. En respuesta a una carta del arzobispo, el cardenal Secretario de Estado no desaprobaba que siguiera editándose La Démocratie, pero sin apartarse de los principios trazados en la Carta del Papa. En cuanto a una posible audiencia, habría que aplazarla para otra ocasión. Sangnier continuaría publicando su periódico. Amette-Merry del Val, 2 y 10 de septiembre y 46075 Merry del Val-Amette, 6 de septiembre de 1910, Ibídem: 15 15-19.

${ }^{144}$ Cuando el presidente de Le Sillon de Saint-Dizier presentó su sumisión al obispo de Langres, asegurando que ese acto representaba a la de todo el movimiento de Haute-Marne, recordaba que continuaban depuestos a trabajar "à la régéneration chrétienne catholique du peuple". “Acte de soumission", La Semaine Catholique 37 (10 septembre 1910) 633-634.

${ }^{145}$ E.-I Mignot-Pie X, 19 septembre 1910, Ibídem: 74-75.

${ }^{146}$ Vid. la carta enviada por la facultad de Medicina y Farmacia de la Universidad Católica de Lille, 5 de septiembre, ASV Segr.Stato 12 (1910) 15 51-52

${ }^{147}$ Así lo hacía el obispo de Evreux. Ph. Meunier-Merry del Val, 14 de septiembre. El Papa actuaba como "doctor infallibilis". P.-F. Beauvain-Pie X, 20 septembre, ASV Segr.Stato 12 (1910) 15 63 y 76. 
La solidaridad entre los sillonnistes permitía el mantenimiento de su periódico. Todos trabajaban gratis para él. Y esa solidaridad haría inútil la prohibición de que la organización se mantuviera exclusivamente bajo la obediencia del obispo diocesano.

En cuanto a la carta pública al Papa, no era el mejor procedimiento. En sus declaraciones para explicarla se situaba en el mismo plano que Pío $X$ y además confiaba en que un día se comprendieran sus ideas. ${ }^{148}$

¿Qué sobrevivió de Le Sillon? Una propuesta que podría resumirse en la opción de encarnar el evangelio en la sociedad y de hacerlo desde la simpatía primero y, luego, desde la solidaridad con los contemporáneos, sin idealizarlos, pero sí eligiéndolos como son para caminar con ellos hacia lo que se piensa y sueña como la mejor posibilidad de ese tiempo. "Nous avons conscience qu'il faut, en nous mêlant à la vie de notre siècle, arriver à l'aimer d'abord, malgré et surtout à cause de ses troubles et de ses misères", decían en su primer manifiesto.

Un estilo de diálogo y encuentro que supone afirmarse afirmando a los otros. Defender las ideas propias y tratar de hacerlas comprender partiendo de aquellas que sostienen los que no las comparten. Una confianza plena en la fuerza de la verdad para abrirse paso, poder ser verdad en cada uno, porque es asumida desde la razón, haciendo así que la adhesión a ella sea personal.

Una forma laica de vivir el cristianismo que, inevitablemente, tiene repercusión en la comunidad católica. La Iglesia dejó de ser laica cuando se identificó su nombre con quienes en ella tienen la misión de la autoridad y del magisterio. Al reducirse de ese modo, inevitablemente, como reconocían los adversarios de Le Sillon, tuvo que asimilarse a un modelo político que, a principios de este siglo, era discutible y para un sector del catolicismo, caduca. Seguir en ella era equivocarse de siglo. Defenderla era apartarse de la mayoría para asociarse no a una minoría, sino a al sector de la clase dominante menos dinámico en el terreno del pensamiento, aunque no lo fue -y esta es una idea que conviene recordar siempreen el de la iniciativa económica, tanto industrial como financiera. ${ }^{149}$

Aquella forma laica era una condición para sintonizar con una sociedad que no había resistido a quienes organizaron las instituciones políticas teniendo como meta dignificar el poder civil, salvaguardar sus prerrogativas y crear a la Iglesia una situación que no le permitiera recuperar prerrogativas que le devolvieran una hegemonía que había durado siglos.

Era inevitable que la acción social -entonces tan "clericalizada", es decir, nada laica- se quedara estrecha para estos católicos "laicos". Pasaron entonces a la acción política. Quisieron en ese primer momento sentirse incluidos en esa orientación de la Iglesia hacia el pueblo. ${ }^{150}$ Les permitió León XIII usar una palabra que les permitía estar unidos a los otros católicos y a los otros ciudadanos.

148 "Le Sillon dopo la cnsura", septiembre 1910, ASV Fondo Benigni 121 55-56.

149 "Il est à remarquer que le Sillon n'a pas soulevé un véritable émoi que du jour où il s'est constitué en groupe politique indépendant, à côté de l'Action libérale". Había intereses electorales. No se habló de ellos, sino de "generalidades" sobre los riesgos de la política. Ariès, N. 1910: 279.

${ }^{150}$ Marc Sangnier, al responder a Mgr. F.-M. Delamaire, arzobispo coadjutor de Cambrai, describió este proceso: primera crítica a una "societé méchante et corrompue". Luego, teorías, limitadas a fórmulas que se mantenían en la esfera de los principios. Hasta ese momento ninguna dificultad crearon a los "sillonnistes" esas "belles et innocentes définitions". Al querer realizarlas, sin someterse a la disciplina de unos partidos políticos, "ne nous I' pas pardonné". L'Eveil Démocratique, 28 juillet 1907. 
"Democracia cristiana" integraba con su designación a los cristianos que trabajaban para mejorar las condiciones inhumanas en las que vivía las clases populares. "Democracia Cristiana" fue también, mientras duró ese clima de libre discusión y de simpatía hacia lo nuevo, una tarjeta de presentación ante quienes postulaban la democracia y sentían la III República como su logro estable tras los anteriores intentos fallidos. Objetivo y estrategia del pontificado de León XIII, situar la Iglesia "en el corazón de la democracia", según la expresión de un sacerdote francés.

No pudo ser entonces. No ha podido ser luego. Pero cada día ha ido a más como propósito y como esperanza. Quienes impiden que los cristianos se proyecten libremente en la sociedad cometen un error. $\mathrm{Y}$, velis nolis, caen en el cinismo de acusar de pérdida de identidad cristiana y condenar a aquellos a quienes previamente se les ha impedido vivir en la Iglesia una fe que sólo en ella crea, expresa y fortalece esa identidad. Cuanto más se amplía esta con exigencias secundarias y hasta superfluas, se reduce la libertad. Mayor es el número de los excluidos o de los que viven como "durmientes" su fe cristiana o su responsabilidad como ciudadanos. A veces las realidades que animaron a una generación parecen muertas. ${ }^{151}$ No es así. Se aletargan para poder sobrevivir. A su hora, despiertan, se yerguen y reanudan su camino.

Quizás no estén los que las iniciaron. Los que les suceden son su mejor memoria. A punto de cerrase la experiencia de Le Sillon, hasta sus adversarios reconocían su derecho a ser así. Y admitían que, fuere cual fuere el nombre que se emplease, quedaba su forma laica de vivir el cristianismo, su estilo de diálogo y encuentro, su opción de encarnar el evangelio en la sociedad y resolver la relación de los católicos con la democracia. Y aún más: el evangelismo brota en la Iglesia de tiempo en tiempo. Ese retorno ingenuo, es decir desde los que nada son, hacia una memoria de Jesús también ingenua -es decir, no legitimadora- tiene un nombre en la Iglesia: Francisco de Asís y los que en él se inspiran. ${ }^{152}$

La condena de Le Sillon repetía la que se hizo tres años con los modernistas. Se les atribuía un sistema, que jamás fue el suyo. Había una expectativa preocupante. Negar la autonomía a los católicos en la esfera civil, abría la puerta a una economía católica, una política católica, un sistema social católico que impondrán a todo el que se someta a la Iglesia. ${ }^{153}$ Para el papa estaba claro que existía "la ciudad católica", como lo dejó claro en la encíclica que "reorganizó" Le Sillon.

Los católicos liberales se propusieron en el verano de 1910 iniciar el proceso de beatificación de Fredéric Ozanam, contando con el apoyo de las Conferencias de San Vicente de Paul, que lo consideraban su fundador, pero fue el P. Bailly. ${ }^{154}$

151 "Le Sillon se dissolvant, son esprit subsisterait; car le Sillon n'est pas seulement une forte organisation, il est un esprit et on ne décrete pas plus facilement la disparution d'un esprit que par la création d'un esprit contraire". Ariès, N. 1910:Le Sillon et le mouvement démocratique...

${ }^{152}$ Un "sillonniste" dijo al director del Express de Lyon que Le Sillon "était un renouveau de l'esprit franciscain". Como sucedió otras veces, también ahora era una pretensión excesiva. "Il est bien difficile, n'est-ce-pas, de réformer à la fois et l'État et l'Église, de fonder de coopératives et de prêcher un Évangile raffiné". Gaucherand, Fréderic. 1910: 20 y 28.

153 Mignot-Loisy, 3 septiembre 1910, Sardella, Louis-Pierre. 2004. Mgr. Eudoxe Irénée Mignot (1842-1918). Un évêque français au temps du modernisme: 579. Paris: Les Éditions du Cerf.

154 Sobre ese intento y la negación de que Ozanan fuera el creador de la Conferencias, Vid. Jerôme de Génève, 9 junio 1910, ASV Fondo Benigni 7955 270. El verdadero fundador fue el P. Bailly, fundador de los Asuncionistas. 
Sus adversarios esperaban que, después de la condena pontificia, la respuesta de los "sillonnistes" fuera moderada. No esperaban que fuera una encíclica, sino una carta del Papa al cardenal Andrieu o al cardenal Amette, arzobispo de París. Esta estrategia de los sostenedores del "modernismo social", tal como lo llamaban los clericales, trataba de no desencadenar represalias y de mantener la confianza de los obispos amigos. El futuro pasaría por la creación de un secretariado personal en torno a Marc Sangnier. Y la continuación de La Démocratie. Se esperaba que los obispos cercanos y amigos prosiguieran protegiendo los "Sillons Catholiques", con consiliarios amigos, que siguieran dirigiendo la acción social diocesana. ${ }^{155}$

El 1 de septiembre Pío X publicó el motu proprio "Sacrorum Antistitum". Se exigía a quienes tenían beneficio eclesiásticos emitir un juramento. Ese acto pontificio coincidía con la condena de Le Sillon. El primero parecía dirigido a frenar la simpatía que en los seminarios podría tener el modernismo. El objetivo era mantener inmunes de contagio a los seminarios. ${ }^{156}$ Además del juramento, los profesores debían someter al obispo el texto y el programa con lo que iban a enseñar. En Alemania se eximió del juramento a quienes enseñaban en centros oficiales. $^{157}$

La condena de Le Sillon se enfrentaba a "l'invadenza modernista nel campo sociale del cattolicesimo, che metteva in pericolo lo spirito delle iniziative democratiche di Leone XIII". ${ }^{158}$

Los dos modernismos estaban localizados, bajo vigilancia y condenados claramente a finales de septiembre de 1910. Lo que vino después demostró que las cosas no eran así.

El modernismo y la fuerza que se le opuso han continuado. René Rémond ha analizado la supervivencia del integrismo hasta los años ochenta, en oposisión al catolicismo identificado en la aceptación del Concilio Vaticano II.

En el sistema de pensamiento del integrismo, el primer rasgo es el rechazo de la historia y del historicismo, en la línea trazada a comienzos del siglo XIX por Joseph de Maistre. No se acepta los cambios, que modifican la sociedad. Eso no quiere decir que los ignore. No los desconoce porque los sufre, pero cree el integrista que no deben tenerse en cuenta, sino que hay que ignorarlos.

Como sociedad perfecta, la Iglesia detenta la verdad. No necesita adaptarla, Pretender eso fue el mayor error del Vaticano I. Estableciendo que la Iglesia es inmutable no percibe que así no la saca de la historia, sino que la hipoteca a una de

155 Esta táctica había tenido ya éxito, consiguiendo que en los Consejos de Vigilancia entraran sacerdotes modernistas. Corresponsal en París, IKS, Marrseilles, 6 septiembre 1910, Ibídem: 7958284.

${ }^{156}$ La reacción de la prensa anticlerical en defensa de los modernistas y contra el Papa "dimostra fino all'evidenza ed illustra di nuova luce quali siano gli ideali ai quali servono. gli obiettivi che si propongono i modernisti", "Modernisti e anticlericali conbtro l'autorità papale", L'Osservatore Romano, 17 settembre 1910, 1.

157 Seminarios y actividad clandestina de los modernistas, dos referencias que rescatan la imagen del trigo y del cizaña tantas veces empleadas por los antiliberales en los años anteriores. "II "motu proprio" di Pio X", L'Osservatore Romano, 10 settembre 1910, 1.

158 "Un rigoroso "motu proprio" del Papa contro le dottrine moderniste y Movimento modernista per la questione del giuramento", La Stampa, settembre 1910, 1 y 3. "Il Vaticano contro i modernisti: un nuovo documento pontificio" La Tribuna, 9 settembre, 5. 
sus fases, olvidando que la Iglesia ha sido una institución que ha ido creciendo, creando, evolucionando.

Fijando la verdad de la Iglesia en ser lo que fue en el siglo XVI, se afirma que durante quince centurias no supo hallar su camino. Rémond designa esto como una "éclatante manifestation du historicisme". Esa sacralización de un momento de su historia hace aparecer el catolicismo como algo grande, pero ya superado.

El integrismo pretende que el catolicismo tiene respuesta para todos los interrogantes y una palabra decisiva en todos los asuntos. Por eso reposa sobre grandes dualidades, que emanan del dentro-fuera de la Iglesia. El mundo es el escenario de dos fuerzas que se disputan el dominio sobre las conciencias. El enemigo del catolicismo y de la Iglesia es el mismo, aunque tenga varios nombres y se presente de diferentes formas.

El más reciente y destacado fue la Revolución Francesa, que hunde sus raíces en la Reforma, el Racionalismo y la llustración. Su heredero es el Liberalismo. Este tiene en el Modernismo su versión religiosa.

Esta divergencia a propósito de la historia y de las realidades de este mundo origina la ruptura entre la Iglesia que hizo y se identificó con el Concilio Vaticano II y el integrismo que se opuso y sigue oponiéndose a él.

De las diversas corrientes presentes en la tradición de la Iglesia, los integristas eligen las que privilegian el verticalismo: la mirada en el Dios todopoderoso, juez soberano, cuya justicia hay que temer, dejando a un lado su misericordia. Es un rasgo de la espiritualidad posterior a Trento: Dios, en su majestad y su gloria, digno de todo honor, que justifica un culto triunfal y rico.

Es una experiencia espiritual que llama a la penitencia por los pecados públicos, que no son más que expresión del poder del mal, empeñado en hacer que Cristo no reine en la sociedad.

Hay una paradoja en el perfil espiritual del integrismo, contradictorio con ese espíritu de conquista, de cruzada. Es la huída del mundo. El hombre y la sociedad están heridos por una enfermedad incurable. No tienen salvación. Este desprecio del mundo y este combate para que la Iglesia ordene la sociedad, coinciden en que ni el cristiano ni la Iglesia tienen nada que aprender, pues están fuera del tiempo. ${ }^{159}$

\section{BIBLIOGRAFÍA}

Ariès, N. 1910. Le Sillon et le mouvement démocratique, Paris:

Barbier, Emmanuel. 1907. La décadence du "Sillon". Histoire documentaire(2), Paris:

Bedeschi, Lorenzo 1987-1988. "L'affaire L. M. Fantoni e la fine de l'amicizia Luigi

Piastrelli-P. Sabatier". Fonti e Documenti 16-17: 489-491.

Desgranges, Jean 1909. Réponse à la Revue Le Sillon, Limoges

Dominici, S. 1995- La lotta senz'odio. II socialismo evangelico del "Seme" (19011915). Milano:

Durand, Jean-Dominique. 2003."Pio X e la Francia": Pio X e il suo tempo, a cura di Gianni La Bella. Bologna: II Mulino

Gaucherand, Fréderic. 1910 Pour quoi?... Lettre à un Sillonniste. Lyon

Loisy, Alfred. 1930. Mémoires pour servir à l'histoire religieuse de notre temps, tome premier 1857-1900. Paris: Émile Nourry Éditeur.

${ }^{159}$ Rémond, René. 1988. “L’intégrisme”. Études 370: 99-105 
Poulat, Émile. 1972. "Dossier historique », en Une oeuvre clandestine d'Henry Bremond. Sylvain Lebrand, Un Clerc qui n'a pas trahi. Alfred Loisy d'après ses mémoires. 1931, Roma: Edizioni di Storia e Letteratura.

Rémond, René. 1988. "L'intégrisme". Études 370: 99-105

Sardella, Louis-Pierre. 2004. Mgr. Eudoxe Irénée Mignot (1842-1918). Un évêque français au temps du modernisme. Paris: Cerf

Sutton, Charles M. 1994, Maurras et les catholiques français. 1890-1914. Nationalisme et positivisme. Paris: Beauchesne. Original publicado en inglés en Cambridge 1982

Zussini Alessandro (a cura di). 1979. "Correspondenza Begey-Sabatier (1899-1918)", Fonti e Documenti 8: 306-307. 